\title{
Equal Culpability and The Scope of the Willful Ignorance Doctrine
}

\author{
[Forthcoming in Legal Theory — please cite only to published version] \\ Alexander Sarch \\ University of Surrey School of Law
}

For some crimes, conviction requires knowledge of an inculpatory proposition. Federal law, for instance, makes it a crime to "knowingly...possess with intent to...distribute...a controlled substance." ${ }^{\prime 1}$ Thus, conviction under this statute requires knowledge ${ }^{2}$ that what one possessed was a controlled substance. Mere recklessness ${ }^{3}$ toward this fact will not suffice.

When a defendant is charged with a knowledge crime, it is common practice among courts to allow willful ignorance of the inculpatory proposition to satisfy the knowledge element of the crime. ${ }^{4}$ So-called willful ignorance jury instructions state that the jury may find the requisite knowledge to be present if the defendant was merely willfully ignorant of the relevant proposition. ${ }^{5}$ Willful ignorance instructions in a drug possession case, for example, might permit the jury to find that the defendant had the knowledge required for conviction if he was willfully ignorant of the fact that the substance he possessed was a narcotic. As I use the term, "the willful ignorance doctrine" refers to the rule that juries may convict a defendant of a crime requiring knowledge even if he was only willfully ignorant of the relevant inculpatory proposition. ${ }^{6}$

\footnotetext{
${ }^{1} 21$ U.S.C. $\S 841(\mathrm{a})(1)$.

${ }^{2}$ Under the Model Penal Code ("MPC"), "[a] person acts knowingly with respect to a material element of an offense" when he is "aware" or "practically certain" that the element obtains (depending on what sort of element it is). MPC $\S 2.02(2)(b)$. Thus, in the criminal law "knowledge requires both belief, or subjective certainty, and the actual truth or existence of the thing known." Robin Charlow, Wilful Ignorance and Criminal Culpability, 70 TEX. L. REV. 1351, 1374-75 (1992). The criminal law notion of knowledge thus is weaker than the philosophical notion of true justified belief plus restrictions to avoid Gettier cases.

3 "A person acts recklessly with respect to a material element of an offense when he consciously disregards a substantial and unjustifiable risk that the material element exists or will result from his conduct." MPC § 2.02(2)(c).

${ }^{4}$ All the federal courts of appeals have endorsed some version of the willful ignorance doctrine. See Global-Tech Appliances, Inc. v. SEB S.A., 131 S. Ct. 2060, 2070 \& n.9 (2011) (collecting cases).

${ }^{5}$ United States v. Heredia, 483 F.3d 913, 917 (9th Cir. 2007) (en banc) (discussing such jury instructions).

${ }^{6}$ The doctrine I am concerned with thus should not be confused with the distinct evidentiary rule recognizing that evidence tending to show willful ignorance can also constitute evidence from which a jury might infer actual knowledge. See, e.g. Global-Tech, 131 S. Ct. at 2073 (Kennedy, J., dissenting) (observing that "[f]acts that support willful blindness are often probative of actual knowledge").
} 
But why may a defendant's willful ignorance be taken to satisfy the knowledge element of the crime charged? What justifies this practice? The Supreme Court recently noted that " $[\mathrm{t}] \mathrm{he}$ traditional rationale for this doctrine is that defendants who behave in [a willfully ignorant] manner are just as culpable as those who have actual knowledge."7 Following Doug Husak and Craig Callender, I call this the equal culpability thesis. ${ }^{8}$

Some might question the willful ignorance doctrine on the ground that if the statute the defendant is charged with violating requires a given mental state (e.g. knowledge), it is unfair to convict him of violating it if he only acted with a different mental state (e.g. willful ignorance). ${ }^{9}$ However, I will set aside such doubts here because the issue is not special to the willful ignorance context. There are many examples of such "substitution principles" in criminal law. ${ }^{10}$

Instead, I mean to investigate a different question: assuming the courts' "traditional rationale" can sometimes justify taking willful ignorance to satisfy the knowledge element of the crime charged, under what conditions would this be legitimate? When, that is, would the “traditional rationale" underwrite willful ignorance jury instructions? If we are to remain faithful to the "traditional rationale," willful ignorance towards the inculpatory proposition should be taken to satisfy the knowledge element of the crime in all but only those cases in which the willfully ignorant defendant really is as culpable as a similarly situated actor with knowledge. Thus, the proper scope of the willful ignorance doctrine would just be the set of cases in which the equal culpability thesis holds. So to determine when willful ignorance instructions are

\footnotetext{
${ }^{7} I d$. at 2069.

${ }^{8}$ Douglas N. Husak and Craig A. Callender, Wilful Ignorance, Knowledge, and the "Equal Culpability" Thesis: A Study of the Deeper Significance of the Principle of Legality, 1994 WIS. L. REV. 29, 53 (1994).

${ }^{9}$ See Husak and Callender, supra note 8 at 58.

${ }^{10}$ For example, negligence can substitute for recklessness "if the actor, due to self-induced intoxication, is unaware of a risk of which he would have been aware had he been sober." MPC § 2.08(2). Similarly, while murder typically requires purpose or knowledge with respect to the victim's death, recklessness can suffice if the circumstances manifest "extreme indifference to the value of human life." MPC $\S 210.2(1)(b)$. See generally Paul H. Robinson, Imputed Criminal Liability, 93 YALE L.J. 609, 616-20 (1984) (discussing several mens rea substitution principles).
} 
warranted on the "traditional rationale," we need to know when the equal culpability thesis itself is true. Are all cases of willfully ignorant misconduct as culpable as knowing misconduct? Or is this true only in some cases of willful ignorance? This is the issue I mean to investigate here.

Section 1 argues against the broadest version of the equal culpability thesis, which employs the most basic understanding of willful ignorance. The reason it is problematic is that sometimes one can be willfully ignorant in the basic sense despite being less culpable than one's similarly situated knowing counterpart. Thus, this unrestricted version of the thesis is over-inclusive.

This suggests that the equal culpability thesis must be restricted to be defensible. In sections 2-4, I consider several such restrictions that have been proposed by Husak and Callender, David Luban, ${ }^{11}$ Alan Michaels ${ }^{12}$ and Deborah Hellman. ${ }^{13}$ These proposals face problems, however. Accordingly, I defend a distinct version of the equal culpability thesis. Drawing on, but further refining, the account I have defended elsewhere, ${ }^{14}$ I argue that willful ignorance involves the breach of a duty of reasonable investigation, and the equal culpability thesis holds when one breaches this duty in a sufficiently serious way before doing the actus reus of the crime.

The aim of this paper thus is to give a limited defense of the equal culpability thesis. If the arguments offered here are sound, the willful ignorance doctrine requires reform. To remain faithful to the courts' "traditional rationale," willful ignorance instructions should not be given in just any case of willful ignorance (as many courts allow ${ }^{15}$ ), but only when it is plausible that the defendant acted with a form of willful ignorance that rendered her conduct as culpable as the

\footnotetext{
${ }^{11}$ David Luban, Contrived Ignorance, 87 GEO. L. J. 957 (1999).

${ }^{12}$ Alan Michaels, Acceptance: The Missing Mental State, 71 S. CAL. L. REV. 953 (1998).

${ }^{13}$ Deborah Hellman, Willfully Blind for Good Reason, 3 CRIM. L. \& PHILOsOPHY 301 (2009).

${ }^{14}$ Alex Sarch, Willful Ignorance, Culpability and the Criminal Law, 88 ST. JoHN's L. REV. 1023 (2014); Alex Sarch, Beyond Willful Ignorance, 88 U. CoLO. L. REV. 97 (2016).

${ }^{15}$ See Heredia, 483 F.3d at 920 (construing the willful ignorance doctrine to require only willful ignorance in what I call the "basic" sense); United States v. Ferrarini, 219 F.3d 145, 154 (2d Cir. 2000) (same); United States v. Flores, 454 F.3d 149, 155 (3d Cir. 2006) (same); United States v. Geisen, 612 F.3d 471, 485-86 (6th Cir. 2010) (same); United States v. Tanner, 628 F.3d 890, 904 (7th Cir. 2010) (same).
} 
analogous knowing misconduct. Thus, identifying a defensible version of the equal culpability thesis places constraints on how the willful ignorance doctrine should be applied in practice.

\section{Basic Willful Ignorance and the Unrestricted Equal Culpability Thesis}

Evaluating the equal culpability thesis requires clarifying the notions of culpability and willful ignorance. In this paper, I work under the assumption that the familiar insufficient regard theory of culpability is roughly correct. Its basic thought is that one is culpable for an action to the extent that it manifests insufficient regard for the protected interests of others (or perhaps more generally, morally relevant considerations). Many philosophers and legal theorists adopt such a theory, ${ }^{16}$ and it is similar in spirit to other well-known accounts of culpability. ${ }^{17}$ For present purposes, we needn't decide exactly how the details are to be developed. The arguments of this paper should go through regardless of how this basic idea is sounds fleshed out, precisely.

However, it is important to note that I will be mainly concerned with legal culpability, as opposed to the possibly distinct notion of moral blameworthiness. ${ }^{18}$ The former, roughly, is that

\footnotetext{
${ }^{16}$ See, e.g., Larry Alexander, Culpability, in The Oxford Handbook of Philosophy of Criminal Law (Deigh, and Dolinko, eds.) (2011) ("acts are culpable when they manifest insufficient concern for the interests of others"); LARry AleXander AND Kimberly Ferzan, CRime AND CulPability 67-68 (2009) (arguing that "insufficient concern [is] the essence of culpability"); NOMY ARPALY AND TIM SCHROEDER, IN PRAISE OF DESIRE 170 ("a person is blameworthy for a wrong action A to the extent that A manifests ill will (or moral indifference) through being rationalized by it"); VICTOR TADROS, CRIMINAL RESPONSIBILITY 250 (2005) ("if [a defendant] is convicted of a serious offence, the state communicates...that [his] behaviour manifested an inappropriate regard for other citizens and their interests"); see generally id. 71-99; Peter Westen, An Attitudinal Theory of Excuse, 25 LAW \& PHILOSOPHY $289,373-74$ ("a person is normatively blameworthy for engaging in conduct that a statute prohibits if he was motivated by an attitude of disrespect for the interests that the statute seeks to protect").

${ }^{17}$ The insufficient regard theory is similar in spirit to the theory that an action is culpable to the degree that "it is a product of a faulty mode of recognition or response to reasons for action." GIDEON YAFFE, ATTEMPTS 38 (2011). See also Julia Markowitz, Acting for the Right Reasons, 119 PhILOSOPHICAL ReVIEW 201 (2010) (discussing the theory that "my action is morally worthy if and only if my motivating reasons for acting coincide with the reasons morally justifying the action"); Peter Graham, A Sketch of a Theory of Blameworthiness, 88 PHILOSOPHY AND PHENOMENOLOGICAL AfFAiRs 388, 407 (2014) (arguing that one is blameworthy iff the reactive emotions are appropriate, and this, in turn, is true iff "in $\phi$-ing, X has violated a moral requirement of respect").

${ }^{18}$ I leave it open whether criminal culpability is same as moral blameworthiness. On my view, defended elsewhere, the legal notion of criminal culpability is a simplified, idealized version of the notion of moral blameworthiness. See Alex Sarch, Who Cares What You Think? Criminal Culpability and the Irrelevance of Unmanifested Mental States (manuscript on file with author). While the moral notion is understood in terms of insufficient regard for morally relevant considerations, the legal notion can be understood in terms of insufficient regard for considerations that the law either does recognize (if we're interested in explaining posited law) or should (if we want to critique the law).
} 
which makes punishment deserved and that substantive criminal prohibitions aim to track, while the latter is what makes one an apt target of the reactive attitudes. (I leave it open exactly how the two are related.) Moreover, I only appeal to one sort of legal culpability. Rather than being concerned with how much culpability this or that jurisdiction actually attributes for a crime, my arguments focus on a normative notion of legal culpability - that is, the amount that jurisdictions like ours ideally should attribute. This paper aims to critically evaluate the law to determine the proper scope of the willful ignorance doctrine. Accordingly, it won't do to simply appeal to the amount of culpability a jurisdiction actually attributes. These attributions may be quite flawed. The aim is to home in on a normatively defensible version of the willful ignorance doctrine, and so I argue in part from what I take to be plausible normative claims about how much culpability should be attributed. But at the same time, to make sure the notion of culpability is genuinely legal, it should also respect the broad, well-settled principles of criminal law in jurisdictions like ours. Thus, the concept of legal culpability I appeal to is not merely descriptive; it is a normatively cleaned up version of the concept that is at work in jurisdictions like ours.

Having clarified the normative notion of criminal culpability I'll be concerned with, let's consider willful ignorance itself. To start, it is widely agreed that willful ignorance is not just a sub-species of criminal law knowledge. Knowledge in the criminal law consists in high subjective certainty plus truth, ${ }^{19}$ and the consensus among courts $^{20}$ and commentators ${ }^{21}$ is that willful ignorance is not knowledge thus understood. If it were, this would vindicate the equal

\footnotetext{
${ }^{19}$ See supra note 2.

${ }^{20}$ United States v. Svoboda, 347 F.3d 471, 477-78 (2d Cir. 2003) (willful ignorance instruction "permits a finding of knowledge even where there is no evidence that the defendant possessed actual knowledge" (internal quotation marks omitted)); United States v. Freeman, 434 F.3d 369, 378 (5th Cir. 2005) ("deliberate indifference charge permits "the jury to convict without finding that the defendant was aware of the existence of illegal conduct"); Global-Tech, 131 S. Ct. at 2072 (Kennedy, J., dissenting) ("[w]illful blindness is not knowledge").

${ }^{21}$ Charlow, supra note 2 at 1390 ("most definitions of wilful ignorance delineate a mens rea that is the equivalent neither of knowledge nor recklessness"); Ira P. Robbins, The Ostrich Instruction: Deliberate Ignorance As A Criminal Mens Rea, 81 J. CRIM. L. \& CRIMINOLOGY 191, 226 (1990) (suggesting "that deliberate ignorance is not knowledge"); Hellman, supra note 13 at 302 (2009) ("contrived ignorance itself is not a form of knowledge"); Husak and Callender, supra, note 8 at 51 (arguing that "wilfully ignorant defendants do not possess knowledge").
} 
culpability thesis, since it would mean any willfully ignorant actor trivially is as culpable as a knowing actor. ${ }^{22}$ But as Husak and Callender show, one can be willfully ignorant of a proposition even if one does not have a high degree of subjective confidence in its truth, as required for knowledge. ${ }^{23}$ Perhaps one merely sees its truth as somewhat (not highly) probable, but deliberately declines to get more information about it, which suffices for willful ignorance.

If willful ignorance is not a form of knowledge, what is it? On the most basic understanding, willful ignorance involves two components. As Glanville Williams put it, a party is willful ignorant if he "has his suspicions aroused but then deliberately omits to make further enquiries." 24 Likewise, the Supreme Court recently observed that most courts agree on "two basic requirements: (1) the defendant must subjectively believe that there is a high probability that a fact exists and (2) the defendant must take deliberate actions to avoid learning of that fact." ${ }^{, 25}$ Given the broad agreement that at least these two prongs are required, I adopt the following as the basic account of the legal concept of willful ignorance:

Basic Willful Ignorance: To be willfully ignorant of an inculpatory proposition $p$ (which let us suppose happens to be true ${ }^{26}$ ), one must

(1) have sufficiently serious suspicions that $p$ is true (i.e. believe that there is a sufficiently high probability that $\mathrm{p}$ is true ${ }^{27}$ ), and

(2) deliberately (as opposed to negligently or recklessly) fail to take reasonably available steps to learn with greater certainty whether $\mathrm{p}$ actually is true.

Unless otherwise indicated, this is how I will understand willful ignorance in this paper. ${ }^{28}$ One quick clarification about "deliberately," a term I adopt from Global-Tech. ${ }^{29}$ Paradigmatically, to

\footnotetext{
${ }^{22}$ This is arguably the strategy employed by the MPC. As the MPC commentary explains, its definition of knowledge in "[p]aragraph [2.02](7) deals with the situation British commentators have denominated "wilful blindness' or 'connivance."” MPC 129-30 (Tent. Draft No. 4, 1955).

${ }^{23}$ Husak and Callender, supra note 8 at 37-38.

${ }^{24}$ Glanville Williams, CRiminal LaW: The General Part, 2d ed., 157 (1961).

${ }^{25}$ Global-Tech, 131 S. Ct. at 2070.

${ }^{26}$ It is not clear if a person can be willfully ignorant of a proposition that is false. However, this need not concern us, since (barring abuses) one is not likely to be charged with a knowledge crime unless the inculpatory proposition is plausibly true. (Granted one might still be charged with the attempt to do the knowledge crime. But since the mens rea for attempt is intent, not knowledge, willful ignorance seems unlikely to figure into many attempt prosecutions.)

${ }^{27}$ I leave it open that what counts as a "sufficiently high probability" here might vary depending on features of the context, e.g. the magnitude of harm that is at stake.
} 
deliberately fail to investigate involves acting with the purpose to preserve one's ignorance. Many courts seem to adopt this meaning of "deliberately preserving one's ignorance." 30 On the other hand, some courts suggest that even when the defendant did not have the purpose to remain in ignorance, a merely knowing failure to investigate can also suffice for willful ignorance. This is suggested especially by courts that require only "conscious avoidance" of inculpatory knowledge. ${ }^{31}$ On this view, one could be willfully ignorant if one acted in ways that one is practically certain will preserve one's ignorance, even if this is not one's purpose or aim. However, I mention this complication only to set it aside. For purposes of clarity, I focus on the first, more familiar type of willful ignorance. (My arguments should mostly go through regardless of which view is adopted, though I will note where it makes a difference.)

As noted below, one might add more elements to the basic account of willful ignorance. Still, the basic account yields the broadest version of the equal culpability thesis that is still plausible:

Unrestricted Equal Culpability Thesis (“UECT”): Suppose A1 and A2 each perform the actus reus of a given crime that requires knowledge of an inculpatory proposition, $\mathrm{p}$. $\mathrm{A} 1$ and $\mathrm{A} 2$, and their respective actions, are identical in every respect except for one: while A1's action is performed with knowledge of $\mathrm{p}, \mathrm{A} 2$ 's action is performed in

\footnotetext{
${ }^{28}$ Note also that Larry Alexander and Kimberly Ferzan have argued that willful ignorance may be regarded as a type of recklessness: "The prototypical willfully ignorant actor is, of course, reckless. The risk he is taking - of, say, smuggling drugs - is an unjustifiable one." Alexander \& Ferzan, supra note 16 at 34. (Hellman criticizes this view, but acknowledges that Alexander \& Ferzan can respond. See Hellman supra note 13 at 311.) Still, the question I address in this paper arises for Alexander and Ferzan's recklessness account, too. They are correct that the willfully ignorant actor generally is at least reckless. But some cases of willful ignorance seem especially culpable —indeed, as culpable as the analogous conduct done with knowledge (practical certainty) of the inculpatory proposition. And one might want to know what it is, precisely, about opting to remain in ignorance about the risks of one's conduct that could increase the actor's culpability from the level of a reckless wrongdoer up to the level of a knowing wrongdoer. It is precisely this question that my account seeks to answer. Thus, my account can be seen as one way of fleshing out Alexander and Ferzan's view that willful ignorance is a form of recklessness. (For related reasons, my account also differs from Tadros's account of willful blindness. See infra note 104.)

29131 S.Ct. at 2070.

${ }^{30}$ See, e.g., Jewell 532 F.2d at 700 (requiring "conscious purpose to disregard the nature of that which was in the vehicle, with a conscious purpose to avoid learning the truth") (emphasis added); Heredia, 483 F.3d at 918 (observing that "when Congress made it a crime to 'knowingly...possess with intent to manufacture, distribute, or dispense, a controlled substance,' (...) it meant to punish not only those who know they possess a controlled substance, but also those who don't know because they don't want to know") (emphasis added). See also Williams, supra note 24 at 157 (noting that a party is willful ignorant if he "has his suspicions aroused but then deliberately omits to make further enquiries because he wishes to remain in ignorance") (emphasis added).

${ }^{31}$ United States v. Ferrarini, 219 F.3d 145, 155 (2d Cir. 2000) (concluding "that the jury was properly instructed that conscious avoidance could...be used to infer knowledge of the conspiracy's unlawful objectives").
} 
willful ignorance of $\mathrm{p}$ in the basic sense. On these suppositions, A2 is (at least) as culpable for her action as A1 is for his.

A number of courts appear to accept this claim. ${ }^{32}$ Nonetheless, UECT is false. As some legal scholars recognize, there are cases in which willfully ignorant individuals seem less culpable than their knowing counterparts. ${ }^{33}$ To see why this is so, let me first explain the challenge for defending UECT. Then I'll argue that the only obvious answer to this challenge fails.

\subsection{A principle about culpability and a question}

The criminal law is often thought to embody the idea that the more confidence one has in the truth of the inculpatory proposition, all else equal, the more culpable one is when one does the actus reus. ${ }^{34}$ More precisely:

Comparative Confidence Principle (CCP): For any two people who commit the actus reus of a crime, if they are identical in all respects except that one is more confident in the truth of the inculpatory proposition, $p$, than the other, then - assuming there are no relevant excuses or justifications, and all else is equal - the person with the greater degree of confidence in $\mathrm{p}$ is more culpable than the one with the lesser degree of confidence in p. $^{35}$

If CCP is correct, it would account for the intuition, say, that lighting a building on fire while aware of a substantial risk that a person is inside (i.e. reckless) is somewhat less culpable-even if just a bit — than lighting it on fire while practically certain (knowing) that a person is inside. ${ }^{36}$

\footnotetext{
${ }^{32}$ The Supreme Court's statement of the "traditional rationale" employs this broad version of the thesis. GlobalTech, 131 S. Ct. at 2069 (noting that the willfully ignorant "are just as culpable as those who have actual knowledge"). See also United States v. Jewell, 532 F.2d 697, 700 (9th Cir. 1976) (en banc) (“deliberate ignorance and positive knowledge are equally culpable"); Heredia, 483 F.3d at 926 (Kleinfeld, J., concurring) ("wilful blindness is 'equally culpable' to...positive knowledge"); United States v. Stadtmauer, 620 F.3d 238, 255 (3d Cir. 2010) United States v. One 1973 Rolls Royce, V.I.N. SRH-16266 By \& Through Goodman, 43 F.3d 794, 808 (3d Cir. 1994) (discussing "the mainstream conception of willful blindness as a state of mind of much greater culpability than simple negligence or recklessness, and more akin to knowledge"); United States v. Rivera, 944 F.2d 1563, 1570 (11th Cir. 1991) (acts of "deliberate ignorance and acts... with positive knowledge are equally culpable").

${ }^{33}$ See Hellman, supra note 13 at 305-12; infra notes 39-45 and accompanying text; Michaels, supra note 12 at 986.

${ }^{34}$ Larry Aleander and Kimberly Ferzan adopt what essentially amounts to this principle. They "are inclined to say that culpability does vary with the actor's estimate of the probability" of the relevant risks. Alexander \& Ferzan, supra note 16 at 38. Charlow also suggests that the criminal law endorses such a principle: "the more certain [the defendant] is that some significant fact exists that will make his conduct criminal, (...) the more blameworthy he is if he goes ahead and acts despite his awareness of that fact." Charlow, supra note 2 at 1394-95.

${ }^{35}$ To be clear, this principle employs one's subjective confidence in the relevant proposition.

${ }^{36} C f$. N.Y. Penal Law $\S 150.15$.
} 
The latter, after all, appears to manifest greater disregard for others than the former.

If $\mathrm{CCP}$ is roughly right, it raises a question about how acting in willful ignorance could possibly be as culpable as knowing misconduct. Defendants for whom a willful ignorance jury instruction is actually needed will fall short of having knowledge of the inculpatory proposition, $p$ (provided the proof at trial suffices). After all, were the defendant certain enough of $p$ to qualify as having knowledge, it would not be necessary to convict her on a willful ignorance theory. Accordingly, when willful ignorance jury instructions really are needed, the defendant will have a lower confidence in $\mathrm{p}$ than a similarly situated actor with knowledge. Thus, by CCP, such a defendant would be less culpable than her knowing counterpart (all else equal).

What, then, could the general feature of willful ignorance be that would always make up for the difference in culpability that $\mathrm{CCP}$ entails will normally exist between actors with a subknowledge degree of belief in $p$ and actors with knowledge that $p$ ? Let " $\mathrm{C}_{\mathrm{R}}$ " be the culpability of doing the actus reus while aware of a substantial risk (i.e. while suspecting) that $\mathrm{p}$ is true, and " $\mathrm{C}_{\mathrm{K}}$ " be the higher culpability level of doing the actus reus while knowing (i.e. while practically certain) that $\mathrm{p}$ is true. Unless we can find something present in all cases of willful ignorance that could fill the gap between $C_{R}$ and $C_{K}-$ call it " $\Delta C$ " - we could not maintain, as UECT asserts, that willfully ignorant misconduct is always as culpable as knowing misconduct.

\subsection{The only obvious answer to the question does not succeed}

The only obvious answer to this question - the only feature common to all cases of willful ignorance that might explain how it could always be as bad as knowing misconduct —is the fact that willfully ignorant actors all deliberately preserve their ignorance about p. However, this answer fails. Sometimes the decision to remain in ignorance can be justified —either fully (such that it is not culpable at all) or partially (such that it is less culpable than it would be absent the justifying circumstances). Sometimes, that is, there can be good reasons for not investigating. In 
that case, the decision not to investigate would manifest less insufficient regard for the protected interests of others than if there were no justification for preserving one's ignorance. Thus, there is no guarantee that the decision to remain in ignorance of $p$ will always provide the required amount of culpability, $\Delta \mathrm{C}$, needed to get the defendant up from $\mathrm{C}_{\mathrm{R}}$ to $\mathrm{C}_{\mathrm{K}}$.

Many sorts of considerations might help justify the decision to remain in ignorance. The simplest concerns the difficulties or dangers of investigating. In general, the more burdensome, dangerous or costly it would be to investigate one's suspicions that $\mathrm{p}$, the less culpable one seems, all else equal, for deciding not to learn whether $\mathrm{p}$ is true. Consider:

Dangerous Investigation: Cory rents a house to Dora, and suspects that Dora might be manufacturing drugs in the basement. Cory could investigate by sneaking into the basement. However, he knows the basement contains a fungus that he and his children are dangerously allergic to (though the allergy is rare in the general population). If Cory comes home with some of the fungus on his clothes, his kids could also suffer a severe allergic reaction. So Cory concludes it is too dangerous to investigate (and there is no one else to do it for him). Accordingly, he decides to preserve his ignorance and avoids going into the house altogether.

If Cory knew the house he was renting to Dora was being used for manufacturing drugs, he could be convicted of aiding and abetting Dora's drug operation. ${ }^{37}$ However, here, Cory does not know this (though, let's suppose, it is in fact true). Nor does Cory's willful ignorance seem to render him as culpable as an analogous knowing wrongdoer. After all, investigating his suspicions would risk a painful (if not deadly) allergic reaction for both himself and his kids, and this seems to at least partially justify his decision to preserve his ignorance. Granted, if investigating entailed no burdens whatsoever (e.g. if he merely was feeling lazy and couldn't be bothered to look in the basement), then the decision to remain in ignorance plausibly would entail enough extra culpability to get him up from $C_{R}$ up to $C_{K}$. But in this case, there are at least some good reasons for him to remain in ignorance. Even if they do not fully justify the decision to remain in

\footnotetext{
${ }^{37}$ United States v. Verners, 53 F.3d 291, 295 (10th Cir. 1995) (affirming conviction for aiding and abetting where mother was aware of the drug operation out of her home).
} 
ignorance, they plausibly do still make him less culpable than the analogous knowing wrongdoer would have been. Thus, we have a counter-example to UECT.

One might object that one cannot be truly willfully ignorant if investigating is not practically possible. But since investigating risks an allergic reaction for Cory and his kids, he has no reasonably available way to investigate. Thus, one might insist, he is not really willfully ignorant. ${ }^{38}$ However, this reply is unconvincing. Granted, if the only way Cory could investigate his suspicions would get him killed, then perhaps we could say investigating is not practically possible or that he has no reasonably available way to investigate. But that is not what we have here. This is a case where the costs of investigating are not so severe as to make the instant investigative methods count as practically impossible or not reasonably available. It is more accurate to say that Cory has an available method of investigation (one that he on balance should use), but it entails risks of pain for himself and his kids. It's doubtful that these risks fully justify his decision to remain in ignorance in this case, but they plausibly do justify it at least partially. Thus, his decision to remain in ignorance still amounts to genuine willful ignorance.

Accordingly, we have an objection to refute UECT. If the gap between $C_{R}$ and $C_{K}$ is especially large (as it would if one has a credence in $\mathrm{p}$ that is well below the knowledge threshold), then having reasons that help justify the decision to remain in ignorance can prevent a willfully ignorant defendant from being as culpable as her knowing counterpart.

Other considerations can also help justify the choice to remain in ignorance. As Deborah

\footnotetext{
${ }^{38}$ The defendant in Heredia argued that she should not be convicted on willful ignorance grounds because she declined to investigate whether her car contained drugs only for safety reasons, given that she was driving on the highway. 483 F.3d at 920. The Ninth Circuit rejected this argument, noting that "[a] decision influenced by coercion, exigent circumstances or lack of meaningful choice is, perforce, not deliberate. A defendant who fails to investigate for these reasons has not deliberately chosen to avoid learning the truth." Id. However, this view can only be taken so far. Clearly, it can't be the case that whenever investigating entails risks or costs, that makes the decision not to investigate non-willful. After all, almost any decision not to investigate will be the result of perceived pressures against investigating. But this cannot mean that hardly anyone is ever willfully ignorant. Instead, only truly exigent circumstances or coercion (etc.) could plausibly make deciding not to investigate count as non-willful.
} 
Hellman has argued, one's professional obligations also might do so. ${ }^{39}$ On her view, criminal defense lawyers and doctors treating patients who claim to suffer from chronic pain can sometimes have a justification, in virtue of their professional roles, for remaining in ignorance. ${ }^{40}$ The defense lawyer might suspect that her client is not telling the truth, thus making the lawyer's arguments to the court potentially perjurious. Nonetheless, in virtue of the lawyer's duties of loyalty and zealous representation, she might be justified in deciding not to investigate her doubts about her client's claims. ${ }^{41}$ Thus, the lawyer plausibly is less culpable than the analogous actor who knows the client is lying and repeats these falsehoods to the court. Similarly, the doctor might suspect that her patient is illegally reselling the prescribed medication, but because of the doctor's duties to the patient, she might be justified in not investigating these suspicions and continuing to prescribe the pain medication anyway. ${ }^{42}$ Such a doctor might not seem as culpable as her knowing counterpart who prescribes medication knowing it will be illegally resold. These cases provide yet further counter-examples to UECT. ${ }^{43}$

Thus, Hellman's cases show that there can sometimes also be ethical costs to investigating, which might lessen the culpability of deciding to remain in ignorance. In other work, I have argued that some non-professional relationships can function analogously. ${ }^{44}$ In particular, the special obligations one owes to family, friends and loved ones give rise to cases where willfully ignorant actors seem less culpable than their knowing counterparts. Consider:

Overly Trusting Parent. Patty and her adult child, Charles, had gone through a long period of estrangement due to Charles' trouble with the law, and they were only

\footnotetext{
${ }^{39}$ See Hellman, supra note 13 at 305-12.

${ }^{40} \mathrm{Id}$.

${ }^{41} I d$. at 305-06.

${ }^{42}$ Id. at 308-09.

${ }^{43}$ Hellman thinks these justifications are supposed to be "objective" in the sense that they apply regardless of whether they actually motivated the actor to remain in ignorance. See id. at 307. I discuss this feature of Hellman's view below in section 4. I want to remain neutral on this aspect of her view for purposes of this article.

${ }^{44}$ See Alex Sarch, Willful Ignorance, Culpability and the Criminal Law, 88 ST. JoHN's L. REv. 1023, 1066-69 (2014); see also Hellman, supra note 13 at 316.
} 
recently reconciled. Thus, Patty is very concerned to rebuild trust with her son. When Charles asks Patty to drive a sealed crate across town to a friend of his, Patty decides not to look inside. She considers the risk that the crate might contain some kind of contraband, and she strongly desires not to take part in any illegal activity. ${ }^{45}$ But after much agonizing, she deliberately chooses not to open the crate or ask Charles to do so because this sign of mistrust would irrevocably damage their recently repaired relationship. It is her conscious object to remain in ignorance because this is the means to preserving her relationship with Charles. And so she sets off across town with the crate in the trunk. On the way, she is pulled over by the police and it turns out that the crate contains drugs.

Patty is willfully ignorant about whether the crate contains drugs, and she likely could be convicted of possession of drugs on a willful ignorance theory. Nonetheless, because there are understandable and plausibly decent reasons for Patty not to investigate her suspicions, she intuitively seems less culpable than someone who acts the same way with knowledge. The person who is told in advance and thus knows that the crate contains drugs, but decides to deliver the package anyway, would seem to display more disregard than Patty did for society's legitimate interest in combating the proliferation of drugs. Thus, although willfully ignorant and very likely somewhat culpable, Patty intuitively is less culpable than her knowing counterpart. ${ }^{46}$

\footnotetext{
${ }^{45}$ To further bolster our intuition about this case, we might also suppose that Patty would not have helped Charles were she certain it would involve transporting illegal items. Thus, she does not satisfy the counterfactual test discussed below in Section 3. However, for the reasons explained there, we must be careful about using intuitions about counterfactual conduct when assessing one's actual culpability.

${ }^{46}$ To this, one might object that Patty perhaps does not purposefully remain in ignorance, but remains in ignorance only knowingly. As a result, she is perhaps not truly willfully ignorant. In that case, this would not be a counterexample to UECT. As noted above, some courts do allow knowingly preserving one's ignorance to count as willful ignorance - especially courts that allow "conscious avoidance" to satisfy the knowledge element of a crime. See supra note 31 and accompanying text. Moreover, even assuming arguendo that willful ignorance requires the purpose to remain in ignorance, Patty still qualifies as willfully ignorant. As stated, Patty deliberately chooses not to investigate whether her son's crate contained illicit items. This is one of her conscious objectives. She aimed at ignorance as the means to achieving her other ends. (In general, to count as bringing about an end E purposefully, one need not aim at $\mathrm{E}$ as an end in itself; rather, it suffices for one to aim at $\mathrm{E}$ as a means to other ends one has. For example, if one kills one's uncle merely as the means to getting one's inheritance, the killing still would count as purposeful. See also Warren Quinn, Actions, Intentions and Consequences, 18 PHILOSOPHY AND PUBLIC AfFAIRS 334, 336 (suggesting that bombing civilians as the means to ending a war is an intentional action that is harder to justify than bombing a munitions factory for the same reason while merely knowing that it will cause civilian casualties).) Since Patty aims at ignorance as the means to preserving her relationship with her son, she remains in ignorance purposefully. So she counts as willfully ignorant.
} 
Accordingly, many cases show UECT to be false. An actor can sometimes have good reasons that help justify the decision not to acquire full-on knowledge, ${ }^{47}$ and so there is no guarantee that doing the actus reus in willful ignorance will always be as culpable as doing it with knowledge.

\section{Restricting the Equal Culpability Thesis: First Pass-Husak \& Callender}

Given the failure of UECT, the obvious response is to restrict the equal culpability thesis. In theory, the restrictions might take one of two forms. First, the restriction might be expressly built into the thesis, so that it would claim that provided certain conditions obtain, acting with willful ignorance in its basic form is at least as culpable as acting with knowledge. Second, one might replace the basic account of willful ignorance with a narrower technical conception of willful ignorance, which one then uses to formulate the equal culpability thesis. I think it matters little which method of restriction is adopted, since either one provides what is needed: a restricted version of the equal culpability thesis. (However, I suspect that the first route is likely to be more transparent than the latter.)

As it happens, courts and commentators seem largely to have taken the second route. For instance, Husak and Callender adopt this narrower conception of willful ignorance:

a defendant is wilfully ignorant of an incriminating proposition $p$ when he is suspicious that $p$ is true, has good reason to think $\mathrm{p}$ true, fails to pursue reliable, quick, and ordinary measures that would enable him to learn the truth of $\mathrm{p}$, and, finally, has a conscious desire to remain ignorant of $\mathrm{p}$ in order to avoid blame or liability in the event that he is detected. ${ }^{48}$

They dub this last requirement-i.e. that one's reason for opting to remain ignorant is the desire "to preserve a possible defense from blame or liability"-the "motivational condition." Eighth, Tenth and Eleventh Circuits take it that this particular reason for remaining ignorant is a

\footnotetext{
${ }^{47}$ I mean for this phrase - "have good reasons that help justify the decision to remain in ignorance"- to be neutral between Hellman's objectivist view and the subjectivist view that one's actual motives matter to the legal notion of criminal culpability. Perhaps having such a reason requires only being in circumstances that help justify remaining in ignorance, or perhaps it requires that the justifying considerations actually were what motivated one to decide not to investigate. Either view is covered by this phrase. See section 4 for more discussion.

${ }^{48}$ Husak and Callender, supra note 8 at 40 (emphasis added).

${ }^{49} \mathrm{Id}$.
} 
necessary part of willful ignorance. ${ }^{50}$ The charitable way to understand what these courts and commentators are up to is to see them as restricting the notion of willful ignorance in order to get a definition of willful ignorance that, if satisfied, makes the defendant especially culpableplausibly as culpable as a knowing actor. Plugging this notion of willful ignorance into the equal culpability thesis would end up restricting it to conditions in which it more plausibly holds:

Restricted Equal Culpability Thesis 1 ("RECT1"): Suppose A1 and A2 each perform the actus reus of a crime requiring knowledge of an inculpatory proposition, p. A1 and $\mathrm{A} 2$, and their respective actions, are identical in every respect except for one: while A1's action is performed with knowledge of p, A2's action is performed in a state of willful ignorance the motive for which was to avoid liability in the event of prosecution. On these suppositions, A2 is (at least) as culpable for her action as A1 is for his.

However, RECT1 also faces problems. Hellman contends it is inappropriate for the criminal law to concern itself with the precise motives of the actor. ${ }^{51}$ Thus, on her view, the doctor who decides not to investigate for bad reasons like the desire to avoid liability should be treated no different for legal purposes than the doctor who decides not to investigate from a justifiable concern for her ethical duties to her patients. ${ }^{52}$ Both actors occupy a professional role that actually justifies their ignorance, she contends. While I think Hellman's view is plausible particularly when it comes to criminal culpability (the legal concept), ${ }^{53}$ others might disagree insofar as they think actual motives can impact even criminal culpability (not just moral blameworthiness). I want to remain neutral on this difficult issue here, however.

Instead, I think RECT1 faces other problems, which both Hellman and those who think motives matter can accept. First, the desire to preserve a defense against liability does not always seem disqualifying, since there can be cases where the defendant's circumstances help justify the

\footnotetext{
${ }^{50}$ United States $v$. Willis, 277 F.3d 1026, 1032 (8th Cir. 2002) (requiring that the defendant, to be willfully blind, had to have "purposely contrived to avoid learning all of the facts in order to have a defense against subsequent prosecution"); United States v. Delreal-Ordones, 213 F.3d 1263, 1268 (10th Cir. 2000) (same); United States v. Puche, 350 F.3d 1137, 1149 (11th Cir. 2003) (same).

${ }^{51}$ Hellman, supra note 13 at 310-11.

${ }^{52} I d$.

${ }^{53}$ I defend the motive-insensitivity of the legal notion of culpability in other work. See Sarch, supra note 16.
} 
desire to preserve a defense and the overall decision to remain ignorant. ${ }^{54}$ Consider a variation of Dangerous Investigation. Suppose Cory not only realizes that investigating would be risky for himself and his kids, but he also wants to preserve a defense against liability should Dora's drug operation (if it exists) be discovered by the authorities. This, in turn, is because Cory is the sole caretaker for his children, and if he gets in trouble with the law for aiding Dora's (possible) drug operation, his kids will be gravely harmed by the appalling foster care system in the city. Accordingly, given the facts Cory is aware of, the decision not to investigate is supported by two considerations: 1) it would prevent his kids from suffering a severe allergic reaction, and 2) by preserving a defense for himself, it makes his kids less likely to suffer at the hands of the broken foster care system. These considerations, grounded in a concern for Cory's children, plausibly provide at least some justification for his decision to remain in ignorance. Accordingly, even though Cory was motivated in part by a desire to preserve a defense, he does not seem as culpable as the analogous wrongdoer who rents the house to Dora knowing that she is engaged in a drug operation. The upshot is that, contrary to what RECT1 asserts, being motivated to remain in ignorance by a desire to preserve a defense does not necessarily make one as culpable as the analogous knowing wrongdoer. (Hellman and the "motives matter" approach might offer different explanations of why this is, but they can both agree RECT1 gets this case wrong.)

In addition, as I've argued elsewhere, RECT1 seems too narrow. ${ }^{55}$ Sometimes there is no way that preserving one's ignorance would seem to help one avoid liability and therefore can be no part of one's motives, but remaining in ignorance still is highly unjustified. Thus, there are cases that fall outside the scope of RECT1, but where the actor still seems just as culpable as his knowing counterpart. Consider:

\footnotetext{
${ }^{54}$ If Hellman's objectivist view is adopted, we can put the point by saying that some actors who preserve their ignorance because they desire to preserve a defense might nonetheless be in justifying circumstances that support their ignorance (regardless of whether these circumstances actually are what motivated them to remain ignorant).

${ }^{55}$ Sarch, supra 44 at 1073-74.
} 
Don't Rock the Boat. Fred works the night shift at a warehouse, and he has heard rumors that the boxes he spends his nights loading and unloading contain drugs. His suspicions are strengthened when the boss starts giving him a weekly bonus for "doing a good job and minding your own business." Fred realizes he could check whether the contents of the boxes are improper by lifting up the box flaps, but not so much that the packing tape rips. However, this would still stretch the packing tape, and Fred thinks there is a chance that investigating in this way might tip off the boss to his snooping. If the boss thinks Fred knows too much, the bonuses will stop and he might lose his job. Fred wants the bonuses, though, and so he doesn't investigate. He does not think that remaining in ignorance would have any benefits in terms of preserving a defense to liability. (Even if his boss were running a drug operation, Fred knows the cops are not skillful enough to uncover it, and even if they did, the authorities would never prosecute.) Instead, the only expected benefit of preserving his ignorance that occurs to him is that it will help him continue to get paid. As it happens, Fred's suspicions were correct: the boss is engaged in transporting drugs and stolen goods, and the weekly bonuses stem from the fruits of this operation. ${ }^{56}$

Fred is willfully ignorant (in the basic sense), but his reason for not investigating is not that he hopes it will help him avoid liability. He thus falls outside of the scope of RECT1. Instead, the only benefit he sees in not investigating is that it will let him continue to get paid. Intuitively, Fred's decision not to investigate is highly unjustified. Thus, he plausibly is just as culpable as a similarly situated person who did Fred's job while knowing what was in the boxes. After all, choosing not to investigate for fear that doing so will prevent one from continuing to get paid seems to demonstrate just as much disregard for legally protected interests as knowingly committing the crime (as some courts have recognized ${ }^{57}$ ). Since RECT1 would not support giving willful ignorance jury instructions for defendants like Fred, RECT1 is too narrow. ${ }^{58}$

\section{Restricting the Equal Culpability Thesis: Second Pass_Luban, Michaels}

\footnotetext{
${ }^{56} I d$.

${ }^{57}$ See, e.g., Jandro v. Ohio Edison Co., 167 F.3d 309, 316 (6th Cir. 1999) ("employer [wa]s virtually certain that harm [wa]s about to occur but cho[se] to 'look the other way' in the interest of continuing the job"); Fiore v. C.I.R., 105 T.C.M. (CCH) 1141, at *30 (Tax Court 2013) (holding that the defendant committed tax fraud because he was willfully blind "for the purpose of getting and keeping clients").

${ }^{58}$ One might try to save RECT1 from this problem by recasting it just as sufficient condition for equal culpability. But that would be unsatisfying because then it could no longer plausibly be a comprehensive account of the conditions in which willful ignorant conduct is as culpable as knowing misconduct. Moreover, it would still suffer from my first objection.
} 
A better-but I'll argue still problematic — way to restrict the equal culpability thesis is the counterfactual approach suggested separately by Alan Michaels and David Luban. The basic idea is that a willfully ignorant actor is at least as culpable as an analogous knowing wrongdoer just in case she would still perform the actus reus of the crime even if she were given full knowledge of the inculpatory proposition.

This approach has been defended most explicitly by Michaels. ${ }^{59} \mathrm{He}$ begins by defining a mental state he dubs acceptance: "The accepting actor is someone who, aware of a substantial risk that a particular circumstance is present or that a particular result might ensue, is so determined to act that he would do so even if he knew the circumstance was present or that the result would ensue." ${ }^{60}$ Michaels then contends that "those who act with [the mental state of] acceptance are as culpable as those who act with knowledge. Those who act without acceptance are less culpable than those who act with knowledge. Therefore, acceptance is neither underinclusive nor overinclusive." ${ }^{61}$ Accordingly, Michaels's view corresponds to the following restricted version of the equal culpability thesis:

Restricted Equal Culpability Thesis 2 (RECT2): Suppose A1 and A2 each perform the actus reus of a crime requiring knowledge of an inculpatory proposition, p. A1 and A2, and their respective actions, are identical in every respect except that A1's action is performed with actual knowledge of $\mathrm{p}$, while A2's action is performed in a state of willful ignorance, and $A 2$ is such that if she were given actual knowledge of $p$, she would still perform the actus reus. On these suppositions, A2 is (at least) as culpable for her action as A1 is for his.

David Luban's discussion of willful ignorance can also be read as an endorsement of the counterfactual test embodied in RECT2. ${ }^{62}$ He suggests that the concept of willful ignorance encompasses three prototypical cases. First, there is the fox, who "aims to do wrong and

\footnotetext{
${ }^{59}$ Michaels, supra note 12.

${ }^{60} \mathrm{Id}$. at 957 .

${ }^{61} I d$. at 995.

${ }^{62}$ Luban, supra note 11 at 968-69.
} 
structures his own ignorance merely to prepare a defense. ${ }^{, 63}$ Second is the unrighteous ostrich who "doesn't want to know she is doing wrong, but would do it even if she knew." half-righteous ostrich "shields herself from guilty knowledge, but would actually do the right thing if the shield were to fail." ${ }^{, 65}$ That is, she, too, does not want to know that what she is doing is wrong, but would not do it if given knowledge that it is wrong.

Luban contends that the fox is as culpable as the purposeful actor, the unrighteous ostrich as culpable as the knowing actor and the half-righteous ostrich as culpable as one who is reckless. ${ }^{66}$ The fox would do the act even if given knowledge of its true nature, and merely is engaged in a clever attempt to set up a defense, and so he seems to act with the purpose of performing the action. ${ }^{67}$ By contrast, the unrighteous ostrich does not affirmatively desire the crime, but would also do it even if given knowledge. Thus, Luban claims the unrighteous ostrich is "precisely fitted for the commonlaw equation of willful ignorance with knowledge," since "[b]y definition, her guilt is unchanged whether she knows or not, because her behavior would be unchanged." ${ }^{\text {, }}$ However, the half-righteous ostrich, "who won't do wrong if she knows, but would prefer not to know, is in a state of conscious avoidance of a substantial and unjustifiable risk of wrongdoingprecisely the [MPC's] definition of recklessness. ${ }^{\prime 69}$

Thus, Luban's discussion suggests that defendants who fit the pattern of either the fox or the unrighteous ostrich would be at least as culpable as a similarly situated wrongdoer with knowledge. Accordingly, the equal culpability thesis would be true of such actors. But since the half-righteous ostrich is only as culpable as a reckless wrongdoer, the equal culpability thesis

\footnotetext{
${ }^{63} I d$. at 969.

${ }^{64} I d$.

${ }^{65} I d$.

${ }^{66} \mathrm{Id}$.

${ }^{67} I d$. at 969 (the fox, "who aims to do wrong and structures his own ignorance merely to prepare a defense, has the same level of culpability as any other willful wrongdoer-the highest level, in the [MPC] schema.").

${ }^{68} \mathrm{Id}$.

${ }^{69} \mathrm{Id}$.
} 
would not hold of defendants in this category. What separates the fox and the unrighteous ostrich from the half-righteous ostrich is that the latter would not do the actus reus if given actual knowledge of the inculpatory proposition, while the fox and the unrighteous ostrich would. Thus, Luban also endorses the counterfactual test for equal culpability embodied in RECT2.

Although RECT2 seems more plausible than RECT1, I argue that RECT2 still suffers from fatal flaws. The problem it faces is an instance of the general criticism that Kenneth Simons has leveled against the counterfactual nature of Michaels' "acceptance" criterion. ${ }^{70}$ Simons points out that punishing on the basis of a counterfactual mental state that one would have acted on, but actually did not act on, amounts to punishing merely for character. ${ }^{71}$ This problem afflicts RECT2 because it allows us to take willfully ignorant defendants who actually lacked knowledge to be just as culpable as knowing wrongdoers solely on the basis of how the former would have behaved under non-actual circumstances. RECT2 thus ties the willfully ignorant defendant's culpability not to the mental state she actually acted with, but rather to a mental state she merely was willing to act with.

This conflicts with a fundamental principle of criminal law. In particular, the criminal law takes it that culpability attributions and resulting punishments must be tied to the nature of one's actual conduct and mental states - not how one would have behaved under nonactual circumstances. As Simons explains, "the harsh sanctions of the criminal law should not be brought to bear on individuals who have not yet done anything wrong, but who merely

\footnotetext{
${ }^{70}$ Kenneth W. Simons, Does Punishment for "Culpable Indifference” Simply Punish for "Bad Character"? Examining the Requisite Connection Between Mens Rea and Actus Reus, 6 BUFF. CRIM. L. REV. 219, 267-75 (2002).

${ }^{71}$ Simons notes that appealing to "counterfactual culpability is highly problematic." Id. at 269. To illustrate, he uses a version of Alexander's case of Deborah who engages in Sunday driving within the speed limit. Id. at 269-70. Suppose she is so callous that "even if she were to come to believe that the risks imposed by her Sunday driving were much higher than she actually believes them to be, she would continue to drive notwithstanding that belief. (...) Deborah is not acting recklessly at this moment and is therefore not culpable. She has an undesirable character trait, one that might dispose her to act recklessly if the circumstances were right, but her counterfactual culpability does not translate into present culpability." Id.
} 
have disreputable — or even dangerous - character traits. (...) We are similarly, and properly, reluctant to impose punishment on a person simply for [attitudes or characteristics] unless and until [they] are expressed in action.,"72 It is for this reason, for example, that when Bill drives off with the intent to kill his uncle but carelessly hits and kills a pedestrian who just happens to be his uncle, we do not say Bill is guilty of murder. ${ }^{73}$ Granted, we know his character is as deplorable as a murderer's, given that he would have killed his uncle intentionally had he gotten the chance. But Bill's culpability for the act at issue-his careless driving - is not as great as the culpability he would have incurred from an intentional killing. In general, it's not true that P's doing A with mental state $\mathrm{M}$ is just as culpable as her doing A with a worse mental state $\mathrm{M}^{*}$ simply because $\mathrm{P}$ would have done $\mathrm{A}$ with $\mathrm{M}^{*}$.

As a result, RECT2 faces counterexamples. Consider a revised version of Overly Trusting Parent. This was the case in which Patty decides not to look in the crate her son asks her to drive across town because she does not want to jeopardize the little bit of trust they had recently rebuilt. I claimed Patty's act was intuitively less culpable than the analogous action would be if performed with full-fledged knowledge that the crate contained drugs. Now add just one small detail: Patty is so concerned not to damage her recently rebuilt relationship with her son that she would have agreed to drive the package across town even if her son had confessed to her that it contained drugs. In fact, however, her son does not tell her this. So she proceeds to drive the crate across town without looking inside-that is, in willful ignorance. Thus, Patty in the revised case- "Patty 2"- performs exactly the same action as Patty in the original version of Overly Trusting Parent_-"Patty 1." Although we know Patty 2 would have been willing to behave the same way even if given full-fledged knowledge of

\footnotetext{
${ }^{72}$ Simons, supra note 70 at 233-34.

${ }^{73} I d$. at 232 .
} 
what the crate contained, this is not actually the mental state she acted with. Thus, the culpability that is manifested in Patty 2's actual conduct in the revised case is exactly the same as the amount of culpability manifested in Patty 1's identical conduct in the original case. If I am correct that Patty 1's culpability for acting as she did in the original case is less than that of the analogous knowing wrongdoer, then the same must be true in the revised case as well. That is, Patty 2 is likewise less culpable for her willfully ignorant conduct in the revised case than the analogous actor with full-fledged knowledge.

Of course, in the revised case, we know that Patty 2's character is as deplorable as that of someone who acts the same way with full-fledged knowledge. But it does not follow that her culpability for her actual conduct (i.e. transporting the crate in willful ignorance) is as great as the culpability she would have incurred from knowingly doing the same thing. It is essential not to allow one's intuitions about the defects in Patty 2's character to infect one's judgment about Patty 2's culpability for her actual conduct. The additional badness in Patty 2's character compared to Patty 1's does not seem to be manifested in what Patty 2 did, since on any natural description, the two actors behaved exactly the same. Thus, if we are careful not to let intuitions about character affect our judgment of how culpable the actor's conduct was, then there should be no barrier to agreeing that Patty 2-just like Patty 1, who behaved the same way-is less culpable for her conduct than the analogous knowing wrongdoer.

Accordingly, we have a counterexample to RECT2. This is a case where a willfully ignorant actor who would perform the actus reus even with knowledge nonetheless is not as culpable for her actual conduct as the analogous knowing wrongdoer would be for hers. The willfully ignorant actor's willingness to do the actus reus even in full knowledge thus is not sufficient for her conduct to be as culpable as the analogous knowing act. 
Nor is this necessary for the willfully ignorant actor's conduct to be as culpable as the analogous knowing misconduct. Sometimes willfully ignorant conduct seems just as culpable as knowing misconduct even though the actor would not perform the actus reus in full knowledge. Suppose Jeff is hired to burn down a Catholic school. Jeff went to Catholic school himself, and became conditioned to be constitutionally unable to knowingly harm any member of the clergy. As Jeff is about to light the school on fire, he notices a car of the sort that priests drive parked outside. Thus, he comes to suspect that a priest is in the building. However, Jeff is aware that he will not be able to go through with the arson if he investigates and learns that a priest is inside. Therefore, wanting to still get paid for the job, Jeff decides not to investigate whether a priest is in the building and he proceeds to light the fire. ${ }^{74}$

It is plausible, I suggest, that Jeff's act, although done in willful ignorance as to the presence of a person in the building, is just as culpable as the analogous act performed with full knowledge that someone is in the building. After all, Jeff's decision not to investigatewhich he knows is the necessary means to being able to go through with the crime and get paid — is highly unjustified, thus making his course of conduct particularly culpable. Indeed, his willfully ignorant conduct seems just as culpable as the analogous knowing misconduct even though it was stipulated that Jeff would not light the building on fire with full knowledge. Accordingly, being willing to perform the actus reus even with full knowledge also is not a necessary condition for a willfully ignorant act to be as culpable as the analogous knowing misconduct.

\section{Restricting the Equal Culpability Thesis: Third Pass-Hellman}

Deborah Hellman's work suggests a different approach to restricting the equal culpability

\footnotetext{
${ }^{74}$ In Luban's terms, Jeff is akin to a fox who simply would not be able to do the actus reus with full knowledge.
} 
thesis. I think this approach is on the right track, but I argue that it, too, requires refinement. Hellman "propose[s] that contrived ignorance [is blameworthy] when the actor's blindness about the relevant fact is not justified." ${ }^{, 75}$ Rather than focus on whether the risks imposed by the actus reus are justified (which is relevant to determine if the actor is reckless), Hellman's "approach... brings this burden of justification to bear on a different decision - the decision to remain blind." ${ }^{, 76}$ Moreover, she clarifies that she "rejects Husak \& Callender's 'motivation' criterion" and claims that "we ought instead to ask whether there are good reasons for the actor to choose blindness rather than focus on what reasons actually motivated the actor in choosing blindness." 77 Formulating this as a version of the equal culpability thesis, we get:

Restricted Equal Culpability Thesis 3 ("RECT3"): Suppose A1 and A2 each perform the actus reus of a crime requiring knowledge of an inculpatory proposition, p. A1 and $\mathrm{A} 2$, and their respective actions, are identical in every respect except that A1's action is performed with actual knowledge of $\mathrm{p}$, while A2's action is performed in a state of willful ignorance toward $\mathrm{p}$ and $A 2$ 's decision to remain ignorant is unjustified. On these suppositions, A2 is (at least) as culpable for her action as A1 is for his.

The main difficulty for RECT3 is that it is over-inclusive. This is because while it's plausible that any instance of unjustified willful ignorance is somewhat culpable, there is no guarantee that it will always provide enough additional culpability to get the willfully ignorant actor up to the level of culpability of the analogous knowing wrongdoer. The mere fact that one's decision to remain in ignorance is unjustified does not always suffice to make one's action as culpable as the corresponding knowing misconduct. Consider:

Product Manager: Karen is in charge of developing a certain drug that cures Alzheimer's if taken early enough. She is aware that there is some risk that the drug will have seriously harmful side effects for people with gene $\mathrm{X}$, who constitute a small portion of the population. She believes there is roughly a $10 \%$ chance that the drug will be harmful to these people. If she releases the drug in awareness of this risk, she would be reckless. Karen knows she could conduct an additional lengthy and expensive study to determine

\footnotetext{
${ }^{75}$ See Hellman, supra note 13 at 312.

${ }^{76} \mathrm{Id}$. at 313 .

${ }^{77} I d$. (emphasis added).
} 
whether the drug really will be harmful to those with gene $\mathrm{X}$ or not. But this would delay the release of the drug, thereby preventing the cure from reaching many early-stage Alzheimer's patients in time to cure them. In light of what she sees (based on her evidence) as the small risk that the drug will harm those with gene $\mathrm{X}$, she decides not to conduct the study and goes ahead and releases the drug. However, suppose that her decision not to investigate the risk further in fact is unjustified-though just barely. In fact, the all things considered better decision would have been to conduct the study.

Karen is willfully ignorant and her decision to remain in ignorance is unjustified, but only very slightly. Hers is a case of nearly justified willful ignorance. I submit that Karen intuitively is less culpable than the analogous knowing wrongdoer-i.e. a product manager who knows that the drug will be harmful to those with gene $\mathrm{X}$, but releases it anyway. Thus, the mere fact that one's decision not to further investigate the risks of the drug is on balance unjustified given one's evidence does not guarantee that one will be as culpable as the analogous knowing wrongdoer. Intuitively, Karen's nearly justified willful ignorance does not suffice to make her as culpable as the analogous knowing product manager. Hence, RECT3 is false. ${ }^{78}$

In addition, one might also take issue with the objectivist flavor of Hellman's view. She is explicit that what matters to culpability, on her view, is whether there exists a justification for remaining ignorant of the truth, regardless of whether this was actually one's motivation for doing so. ${ }^{79}$ But others might think that actual motives make all the difference to culpability.

I can't resolve this thorny issue here. But even those who are sympathetic to Hellman's view as applied to criminal culpability (as opposed to moral blame) might still worry that her view is overly objectivist. Quite plausibly, to get the benefit (for legal purposes) of a justifying reason that supports the decision to remain in ignorance, one must at the very least be aware of the facts

\footnotetext{
${ }^{78}$ To be fair, Hellman might be read as aiming only to lay out the conditions under which willful ignorance is culpable at all — not to specify when willful ignorance followed by a subsequent reckless actus reus is as culpable as the analogous knowing misconduct, which is my focus here. Thus, it seems Hellman plausibly has identified a necessary condition for the equal culpability thesis to be true - namely, that one's decision to remain in ignorance is not justified - but it is not a sufficient condition.

${ }^{79}$ Hellman, supra note 13 at $310-12$.
} 
constituting this reason. ${ }^{80}$ However, for all Hellman says, it remains possible that one could get the benefit of justifying circumstances that objectively exist even if one is not aware of them. Her own presentation of her view is at least ambiguous on this point. As she puts it, "[a]n actor is culpably blind if his blindness is unjustified. Blindness is justified when the reasons to remain ignorant outweigh the reasons to investigate, all things considered. (...) If there are no good reasons for [remaining ignorant], this blindness is culpable." ${ }^{" 81}$ Thus, for all Hellman says, it is possible that as long as the actor is in circumstances (e.g. occupies the right kind of professional role) that would objectively justify the decision to remain in ignorance, the actor would get the benefit of this justification even if she is unaware of the facts or circumstances that these justifying reasons exist in virtue of.

Recall Karen. She is in circumstances that provide some, but not a full justification for deciding not to do the additional study. She is a bit culpable for her decision to remain in ignorance, but not very. Now compare Lauren, who is just like Karen, except that she is entirely unaware of the burdens that the study would entail for the patients who would go untreated because of the delay in releasing the drug. This thought does not even cross Lauren's mind. Instead, the only consideration she is aware of that she might claim in support of not doing the study is that it would involve a lot more work for her. Accordingly, Lauren seems more culpable for deciding to remain in ignorance than Karen does. However, on the strongly objectivist interpretation of Hellman's view, Karen and Lauren would both have the same level of culpability, since they both actually are in the same circumstances.

But this is implausible. Hellman's own presentation of her view does not clearly rule out this

\footnotetext{
${ }^{80}$ Alexander and Ferzan endorse this view as well. Alexander \& Ferzan, supra note 16 at $60-61$. I also defend such a view. See Sarch, supra note 18.

${ }^{81}$ Hellman, supra note 13 at 315 (emphasis added). See also id. at 313 ("we ought...to ask whether there are good reasons for the actor to choose blindness rather than focus on what reasons actually motivated the actor in choosing blindness").
} 
possibility, but it should. At the very least, we should take it that one is culpable to the extent that one's decision to remain in ignorance is unjustified on the facts as one believes them to be. This would let us say that Lauren is more culpable than Karen. Lauren, after all, is aware of fewer considerations that help justify her ignorance than Karen is aware of.

To avoid these problems for RECT3, the equal culpability thesis needs to be further refined. It should be restricted to cases where the decision to remain in ignorance really is sufficiently culpable to get the willfully ignorant actor up to the culpability level of her knowing counterpart. Moreover, it should avoid the strongly objectivist interpretation of Hellman's position.

\section{Restricting the Equal Culpability Thesis: The Duty of Reasonable Investigation}

In this Section, I defend a different version of the equal culpability thesis, which draws on and deepens the account of willful ignorance I've offered elsewhere. ${ }^{82}$ We saw that the UECT failed because sometimes the willfully ignorant actor's decision not to investigate can be at least partially justified. This can prevent the decision to remain in ignorance from providing enough added culpability to get one up from a sub-knowledge culpability level to the level of a knowing wrongdoer. My account is premised on the thought that sometimes the decision not to investigate can fill this gap. I claim that willful ignorance involves the breach of a duty of reasonable investigation, and willfully ignorant conduct is as culpable as the analogous knowing misconduct when this duty is breached in sufficiently serious ways. Thus, I aim to defend:

Restricted Equal Culpability Thesis 4 ("RECT4"): Suppose A1 and A2 each perform the actus reus of a crime requiring knowledge of an inculpatory proposition, p. A1 and A2, and their respective actions, are identical in every respect except for one: while A1's action is performed with knowledge of $\mathrm{p}, \mathrm{A} 2$ 's action is performed with a form of willful ignorance toward $p$ that involves a sufficiently culpable breach of the duty of investigation. On these suppositions, $\mathrm{A} 2$ is (at least) as culpable for her action as A1 is for his.

\footnotetext{
${ }^{82}$ See Sarch, supra note 14.
} 
Defending RECT4 requires three main claims: 1) there is a duty of investigation, 2) breaching it makes one's conduct more culpable than if no investigations had been feasible, and 3) this added culpability can sometimes suffice to make one's conduct as culpable as the analogous knowing misconduct. I will argue for each in turn.

RECT4 is supposed to be an improvement over Hellman's account not only because it avoids the problems outlined above, but also because it will be supplemented by an account of the culpability of breaching the duty to investigate. RECT4, by itself, does not say much. It just abstractly describes the conditions in which willfully ignorant misconduct is as culpable as the analogous knowing misconduct. However, by explaining why it is culpable to breach the duty to investigate and what factors determine how culpable such a breach is, we can home in on the conditions in which the equal culpability thesis holds. ${ }^{83}$

\subsection{There is a duty of reasonable investigation}

The first order of business is to explain the duty to investigate. Nomy Arpaly and Tim Schroeder have recently argued that it is implausible to think that there is a duty to "become informed about morally important matters, to double check our morally relevant beliefs and do our best to make sure that they are true." ${ }^{\prime 84}$ Their primary concern is that "we cannot in general know which of our beliefs need checking. ${ }^{, 85}$ After all, "it is not the case that [we are] under a moral obligation to scrutinize all of [our] beliefs regarding" morally important matters. ${ }^{86}$

\footnotetext{
${ }^{83}$ Note one limitation of my account, which has been implicit in the discussion thus far. I only aim to explain what makes defendants with a sub-knowledge level of confidence in the inculpatory proposition, $\mathrm{p}$, as culpable as a knowing wrongdoer. Some have suggested that one can be willfully ignorant despite knowing p. See Husak and Callender, supra note 8 at 48. I am skeptical of this view, however, because if one has enough certainty in the inculpatory proposition to count as knowing it, then it seems implausible to describe one as ignorant of that proposition. Moreover, someone who actually knows $\mathrm{p}$ can be straightforwardly convicted of the knowledge crime in question (provided the evidence suffices). Indeed, it is only when one has a sub-knowledge level of certainty in $p$ that any puzzle arises about how one can be as culpable as a knowing wrongdoer. This is the puzzle I aim to answer. ${ }^{84}$ Nomy ARPALY \& Tim Schroeder, IN PRAISE OF DeSiRe 237 (2014).

${ }^{85} \mathrm{Id}$.

${ }^{86} \mathrm{Id}$.
} 
I think Arpaly and Schroeder's worry is correct, as far as it goes. But my account avoids the concern because the duty of investigation I postulate is limited to a very specific context, which is especially morally loaded. My claim is only that the awareness that one's intended conduct would create a risk of harm or illegality gives rise to a duty to investigate in reasonable ways. I do not claim that all morally important beliefs require "checking." Rather, only one specific kind triggers the need to investigate: namely, the belief that some action one plans to perform would pose substantial risks to the interests of others (e.g. by causing harm or otherwise being illegal). ${ }^{87}$

When one possesses such a belief, one's primary duty is of course to refrain from performing the risky action in question. However, on my view, this is not the only duty one incurs. The primary duty not to act in certain ways can give rise to secondary duties - as happens when breaking a promise or wrongfully injuring someone creates a duty to apologize or offer compensation. ${ }^{88}$ In addition to secondary duties that arise after the breach of a primary duty, there are also secondary duties that arise before such a breach, as would be the case if one is planning to break a promise and there are preemptive steps one should take to mitigate the

\footnotetext{
${ }^{87}$ Others have discussed similar duties to investigate, but none have systematically developed the precise duty I defend here. Holly Smith mentions the case of a driver who "should have checked his mirror earlier, but given that he did not, he should check it now rather than back down the driveway." Holly Smith, Culpable Ignorance, 92 Philosophical Rev. 543, 546 (1983). See also George Sher, Who Knew? Responsibility Without AWARENESS 111-12 (2009) (discussing the idea that one's moral obligations can give rise to secondary epistemic duties to be or become aware of morally relevant features of one's situation); William K. Clifford, The Ethics of Belief, in The Ethics of Belief AND Other Essays, 70-96 (T. Madigan ed., 1999) (famously defending-in 1877 - a broad and weighty moral "duty of inquiry").

Tadros also posits a duty to investigate, and like me, he thinks the duty can be reduced in stringency where investigating is dangerous or difficult. Tadros, supra note 16 at 246-47. However, Tadros's duty to investigate is much broader than mine, covering not only actors who actually have suspicions of the risk to be investigated but also actors who do not. Thus, his duty to investigate also covers some instances of negligent unawareness of the risk (or what U.K. courts call objective recklessness). By contrast, my duty to investigate applies only where one already has some suspicions or awareness of the risk (i.e. is subjectively reckless). Thus, my account focuses on the failures of inquiry that plausibly can provide a basis for treating one as a knowing wrongdoer. (See also infra note 104.)

${ }^{88}$ See, e.g. Gregory Keating, The Priority of Respect Over Repair, 18 LEGAL TheORY 293, 309 (2012) (observing that "[r]emedial responsibilities arise out of the breach of antecedent primary duties" and criticizing the corrective justice theory of tort for not capturing the priority of primary duties over the secondary duties they generate); John Gardner, What Is Tort Law For? Part 1: The Place of Corrective Justice, 30 LAW \& PHIL. 1, 33-35 (2011).
} 
inconvenience it will cause the promisee. The duty to reasonably investigate likewise is a secondary duty that arises in anticipation of subsequent wrongdoing.

More specifically, this duty arises under conditions like the following. Suppose one is aware that some future action one could perform would pose a substantial and unjustified risk of harm to interests that are legitimately protected by the law, as would be the case whenever one has suspicions about the inculpatory proposition of a crime and there is no justification or excuse. Moreover, suppose one plans or intends to perform the act in question. ${ }^{89}$ In such a case, I submit, one would have a secondary duty, deriving from one's primary duty not to perform the underlying action, to make reasonable investigations before performing the underlying action ${ }^{90}$ (provided one remains intent on doing it). ${ }^{91}$ Thus, the conditional duty I postulate is this:

Duty of Reasonable Investigation (DRI): If i) one is intending or planning ${ }^{92}$ to perform the actus reus of a crime, ii) one possesses substantial confidence (short of knowledge) that the associated inculpatory proposition, $\mathrm{p}$, is true (but lacks reason to think the risk of p's truth is somehow justified), and iii) one believes or reasonably should believe that there are available ways to investigate whether $p$ that are not unduly burdensome, then one has a pro tanto obligation, conditional on continuing to hold the relevant intention, to (at least try to) acquire more information, in reasonably available ways (if any), about whether $\mathrm{p}$ is true or false before performing the actus reus.

\footnotetext{
${ }^{89}$ One might think that the duty to investigate arises not just when one intends or plans to perform the underlying risky action, but even when one merely seriously considers whether to perform it. I leave that question open here.

${ }^{90}$ More precisely, there is such a duty here only assuming the law is just. The duty to reasonably investigate, to be normatively defensible, ideally should not be triggered if the criminal statute in question is substantively unjust. Of course, the law often is unjust. Thus, the law might impose what amounts to a duty of investigation in conditions when, normatively speaking, it should not. (Perhaps this is the case with certain harsh drug laws in the U.S., for example.) Does this mean courts must evaluate whether the law is just before applying the willful ignorance doctrine? (Thanks to an anonymous reviewer for this worry.) The answer is no. Courts themselves should not have to make such a determination. Given their role, their main task is to apply the law as given. However, my question as a theorist is different from the court's. Since I'm concerned with normative culpability (i.e. the amount of culpability that the law should attribute), all I am claiming is that there should (from the theorist's point of view) be a legal duty to investigate only where the law actually is just (again, as evaluated from the theorist's point of view).

${ }^{91}$ It's conceivable that the investigations one has a duty to perform are not just external investigations aimed at collecting more information. I want to leave open the possibility that the required investigations merely involve further processing or reflection on information one already has. For example, one might see several red flags, but then consciously decide not to think about the matter any further to prevent oneself from putting the pieces together and becoming certain that one's planned conduct would cause harm. Perhaps this could count as willful ignorance.

92 The term "planning" is included here because it may well be possible that some lesser degree of commitment, short of an irrevocable intention to do the underlying act, also triggers the duty to investigate.
} 
Thus, suppose Brad plans to set fire to a building despite being aware of a substantial chance that someone is inside. When Brad has settled on this less-than-ideal course of action, DRI says he has a conditional duty to stop and investigate in reasonably feasible ways before proceeding - for example, by looking inside the building. The duty is conditional in the sense that if Brad were to abandon his plan, his corresponding duty of investigation would evaporate. ${ }^{93}{ }^{94}$ Moreover, his duty to investigate is pro tanto in the sense that it can in principle be outweighed by other considerations, e.g. if complying with the duty of investigation would make it too hard to comply with the primary duty not to do the actus reus, or if investigating otherwise proved to be overly harmful or costly. Furthermore, the duty to investigate of course covers not only actively acquiring new information (where appropriate), but also not blocking information one would have received otherwise. After all, the duty to investigate whether $p$ entails that one should not act in ways that prevent one from learning whether $\mathrm{p}$. One minimal form of investigation is refraining from taking steps to block oneself from learning the truth.

One might wonder how one's beliefs about whether one can reasonably investigate impact one's pro tanto obligation to do so. ${ }^{95}$ While the argument of this paper doesn't depend on it, I incline toward the following view (and have formulated DRI accordingly). First, if one actually can feasibly investigate, although one does not know it (and wouldn't be expected to know it

\footnotetext{
${ }^{93}$ One might worry that this gives Brad an easy way to sidestep his duty to investigate: perhaps he could simply withdraw his intention to burn down the building until the very last moment, and thereby avoid incurring any secondary duty to investigate before starting the fire. However, on closer inspection, such a strategy would never succeed. Were Brad to adopt such a scheme, he would not genuinely be abandoning his plan or intention to burn down the building. Instead, he would merely be executing an elaborate plan to burn it down that involves a generous helping of self-deception. Accordingly, the intention that triggers the duty to investigate would remain in place.

${ }^{94}$ Because the duty of investigation is triggered only when the defendant believes the act he is planning would pose a substantial and unjustified risk of harm or illegality (or an unjustified risk that the inculpatory proposition is true), DRI can accommodate cases where exigent circumstances prevent the need to investigate from arising at all. Suppose Laura knows the building must be burnt down to halt a fire that is rapidly spreading towards town, but she realizes that there is little time to check if someone is inside. It is not impossible to do so, but it would leave less time for other important precautions (e.g. warning the town authorities). One might think the best way to describe this situation is not to say that Laura would be justified in breaching the duty of investigation, but rather that such a duty does not arise at all. It is to leave room for this possibility that DRI says that the duty to investigate arises only if the substantial risk one is aware of is unjustified.

${ }^{95}$ Thanks to Kimberly Ferzan for pressing me on this issue.
} 
given one's evidence), then DRI is not triggered.${ }^{96}$ By contrast, if one (reasonably) believes one can feasibly investigate, but one is mistaken, then I take it one has a pro tanto obligation at least to attempt to investigate. After all, it arguably shows some lack of regard for others, and thus some culpability, to fail to even try to investigate in ways that plausibly seem available. ${ }^{97}$

Note finally that in complying with DRI, what one learns about the inculpatory proposition can impact the stringency of one's primary duty not to do the actus reus. Recall Brad. If he investigates as required, there are three possibilities. First, he might learn that there is a greater chance than expected that someone is in the building. This would strengthen his primary duty not to set it on fire. He would display more culpability were he to start the fire with this increased certainty that someone is inside (a consequence of $\mathrm{CCP}$ ). Second, he might learn that there is a smaller chance than expected that someone is inside. If so, his duty not to start the fire would be weakened (though it would persist due to the independent reasons not to set even unoccupied buildings on fire). Third, the strength of his duty not to start the fire would remain unchanged if investigating did not alter his estimate of the likelihood that someone is in the building.

\subsection{Why one's culpability is affected by whether one breaches DRI}

To explain why acting in willful ignorance is more culpable than purely reckless action—and indeed sometimes is as culpable as acting knowingly-I argue that breaching DRI can itself be an independent source of culpability. The key claim to be shown is that failing to investigate as DRI requires and then performing the underlying risky action is more culpable (provided one has no relevant excuse or justification) than it would be to perform the same risky action when

\footnotetext{
${ }^{96}$ What about the case where one actually does not know one can investigate, but even if one did, one wouldn't do it? DRI entails that if one reasonably should be aware of available investigative steps, one has a pro tanto obligation to use them. But I take it that the counterfactual truth that one would not investigate even if one knew one could doesn't directly bear on one's culpability - for the same reasons I rejected the counterfactual test in RECT2.

${ }^{97}$ One might doubt that this is true in the event that one only unreasonably believes one can investigate. This is a difficult issue that I do not have room to fully settle here. I have formulated DRI so that one's pro tanto obligation to investigate is triggered even by the unreasonable belief that there are feasible ways to do so, but I acknowledge that this might be controversial. My main argument in any case doesn't depend on it.
} 
investigating is not an option (in which case DRI is not breached and the actus reus would be done merely recklessly). More precisely:

Added Culpability Thesis: For any person, A, to whom DRI applies, if A breaches DRI and proceeds to perform the underlying actus reus that DRI required $A$ to investigate the risks of, then in virtue of this breach, $\mathrm{A}$ is at least a little bit more culpable for his conduct (provided he has no justification or excuse) than a similarly situated person, B, who performs the same actus reus but had no reasonable way to investigate the risks of that action, would be for her conduct.

I take this claim to be intuitive, but let me also offer an argument for it. Having done so, I then give a more general account of how complying with or breaching DRI impacts culpability.

The argument for the Added Culpability Thesis is that—-from the actor's perspective- doing the underlying risky action having breached the duty to investigate involves two missed chances to assure oneself that one's conduct will not be wrongful, while doing the risky action when investigating is not an option involves only one. Suppose I intend to do an action at $t 1$ that I am aware will be risky. Moreover, I realize I can feasibly investigate at an earlier time, $t 0$, whether this risk really will materialize after I act at $t 1$. My first chance to assure myself that my intended conduct will not be wrongful comes at $t 0$. As things seem to me then, if I investigate, I might learn that the risk in question will not materialize. But if I fail to investigate, while keeping my intention to do the risky action (and I have no justification or excuse), I manifest a lack of due regard for others that contributes to my culpability. However, my overall culpability level is not yet fixed at $t 0$ because I have a second chance to assure myself that my intended conduct will not be wrongful-i.e. during the period up to $t 1$. After all, until $t 1$, I can simply abandon my intention to perform the risky action at $t 1$. Going ahead with that action is another manifestation of insufficient regard for others. Thus, breaching DRI and carrying out the risky action involves two missed chances (one epistemic and the other practical) to rule out the possibility that conduct that I intend is wrongful. By contrast, when I have no feasible way to investigate, performing the 
underlying risky action only involves one such missed opportunity, and thus only one manifestation of insufficient regard. Accordingly, breaching DRI and doing the risky action is more culpable than doing that action when investigating is not an option-just as the Added Culpability Thesis says.

One might think there is something odd about my claim that breaching DRI is an independent source of culpability. Arpaly and Schroeder, for instance, object to the idea of such a duty on the ground that complying with it would "not absolve one of moral blame."98 After all, even if one investigates as DRI requires, one might still proceed to behave culpably. If one learns that the inculpatory proposition is true, but performs the actus reus anyway, then one would be a knowing wrongdoer and display a correspondingly high level of culpability. Thus, even if one complies with DRI, one might display more on-balance culpability than others who fail to investigate as DRI requires - e.g. those who don't investigate but then have a change of heart and do not do the actus reus. Accordingly, there is no guarantee that someone who breaches DRI will be on-balance more culpable than someone who complies with it. In what sense, then, can failing to investigate be independently culpable? ${ }^{99}$

These considerations are in fact consistent with my account. I don't claim that investigating as DRI requires fully absolves one of blame. Nor do I claim that it always renders one onbalance less culpable than someone who breaches DRI. Rather, I contend only that, in virtue of breaching DRI, there is one respect in which one is more culpable than someone who complies with DRI. This leaves open the possibility someone who investigates might still be on-balance more culpable than someone who does not. Thus, my basic claim about the relative culpability of breaching versus complying with DRI is this:

\footnotetext{
${ }^{98}$ Supra, note 84 at 238.

${ }^{99}$ A related worry is discussed below. See infra notes 105-108 and accompanying text.
} 
Culpability for Breach vs. Compliance ("CBC"): For any two similarly situated individuals, $\mathrm{X}$ and $\mathrm{Y}$, if $\mathrm{X}$ breaches DRI while $\mathrm{Y}$ does not breach DRI (either by complying with it or its not applying), then (in virtue of X's breach) there is at least one respect in which $\mathrm{X}$ is more culpable than $\mathrm{Y}$ - even if $\mathrm{Y}$ (in virtue of other features of her behavior) ultimately is on-balance more culpable than $\mathrm{X}$.

CBC is compatible with cases where complying with DRI seems on-balance more culpable than breaching it - e.g. if $\mathrm{Y}$ investigates and learns that the inculpatory proposition is true but does the actus reus anyway, as compared with $\mathrm{X}$ who breaches DRI but decides not to do the actus reus after all. All CBC says is that there is one respect in which $\mathrm{X}$ is more culpable than Y. Moreover, the Added Culpability Thesis fits naturally with CBC. The Added Culpability Thesis compares the culpability of two similarly situated people, labeled A and B above, who both do the actus reus with suspicions about the inculpatory proposition, where A breaches DRI but B cannot reasonably investigate (so that DRI does not apply and is not breached). CBC suggests there is one respect in which $\mathrm{A}$ is more culpable than $\mathrm{B}$. Thus, since all else is equal (i.e. $\mathrm{A}$ and $\mathrm{B}$ are "similarly situated"), A is also on-balance a bit more culpable than B-just as the Added Culpability Thesis claims.

To further flesh out $\mathrm{CBC}$, we can map out the culpability of complying with or breaching DRI as follows. When DRI applies to the actor, there are three main variables: 1) whether the actor investigates at $t 0$ as DRI requires; 2) whether the inculpatory proposition, $\mathrm{p}$, is true (such that investigating would raise the actor's credence in $\mathrm{p}$ ) or false (such that investigating would lower her credence in p); ${ }^{100}$ and 3) whether the actor proceeds to perform the actus reus at $t 1$. Given these three variables, there are eight cases in which DRI applies. The following table summarizes CBC's implications about the actor's culpability in each:

\footnotetext{
${ }^{100}$ It is a simplifying assumption of my model that when the inculpatory proposition $\mathrm{p}$ is true, investigating would lead one to acquire greater certainty that $\mathrm{p}$, while when $\mathrm{p}$ is false, investigating would lower one's certainty that $\mathrm{p}$. However, this will not always be accurate. It is possible that $\mathrm{p}$ is false, but investigating under the circumstances would yield evidence that raises one's credence in p. However, I set aside this complication here to keep the model simple. It can be expanded to capture this additional winkle if needed.
} 


\begin{tabular}{|c|c|c|c|c|}
\hline & $\begin{array}{l}\text { A investigates at } t 0 ; \\
\text { does actus reus at } \\
t 1\end{array}$ & $\begin{array}{l}\text { A investigates } \\
\text { at } t 0 ; \text { does not } \\
\text { do actus reus } \\
\text { at } t 1\end{array}$ & $\begin{array}{l}\text { A does not } \\
\text { investigate at } t 0 ; \text { does } \\
\text { actus reus at } t 1 \text { (= } \\
\text { willful ignorance) }\end{array}$ & $\begin{array}{l}\text { A does not investigate } \\
\text { at } t 0 ; \text { does not do actus } \\
\text { reus at } t 1\end{array}$ \\
\hline $\begin{array}{l}P \text { is true; } A \\
\text { would learn } \\
\text { upon } \\
\text { investigating } \\
\text { that } P \text { is } \\
\text { more likely } \\
\text { than initially } \\
\text { believed }\end{array}$ & $\begin{array}{l}\text { Case 1: A manifests } \\
\text { no insufficient } \\
\text { regard at } t 0 \text {, but } \\
\text { manifests extreme } \\
\text { insufficient regard at } \\
t 1 \text { (as much as a } \\
\text { knowing actor). }\end{array}$ & $\begin{array}{l}\text { Case 3: A } \\
\text { manifests no } \\
\text { insufficient } \\
\text { regard at } t 0 \text { or } \\
\text { at } t 1 .\end{array}$ & $\begin{array}{l}\text { Case 5: A manifests } \\
\text { some insufficient } \\
\text { regard at } t 0 \text {, and } \\
\text { manifests substantial } \\
\text { insufficient regard at } \\
t 1 \text {. A's total culpability } \\
\text { is the sum of the } \\
\text { culpability displayed } \\
\text { at } t 0 \text { and at } t 1 \text {. }\end{array}$ & $\begin{array}{l}\text { Case 7: A manifests } \\
\text { some insufficient regard } \\
\text { at } t 0 \text {, but manifests no } \\
\text { insufficient regard at } t 1 \text {. } \\
\text { A's total culpability } \\
\text { level likely is far less } \\
\text { than the amount needed } \\
\text { to be criminally liable. }\end{array}$ \\
\hline $\begin{array}{l}\text { P is false; } A \\
\text { would learn } \\
\text { upon } \\
\text { investigating } \\
\text { that } P \text { is less } \\
\text { likely than } \\
\text { initially } \\
\text { believed }\end{array}$ & $\begin{array}{l}\text { Case 2: A manifests } \\
\text { no insufficient } \\
\text { regard at } t 0, \text { and } \\
\text { manifests less } \\
\text { insufficient regard at } \\
t 1 \text { than if her initial } \\
\text { credence in P had } \\
\text { not been lowered. }\end{array}$ & $\begin{array}{l}\text { Case } 4: \text { A } \\
\text { manifests no } \\
\text { insufficient } \\
\text { regard at } t 0 \text { or } \\
\text { at } t 1 .\end{array}$ & $\begin{array}{l}\text { Case 6: Same as case } \\
5 \text {, except that A will } \\
\text { not face criminal } \\
\text { liability because } P \text { is } \\
\text { false. (A is as culpable } \\
\text { as in Case 5, but gets } \\
\text { lucky since P is false.) }\end{array}$ & Case 8: Same as case 7. \\
\hline
\end{tabular}

Case 1 is the scenario that worried Arpaly and Schroeder. But, as seen, it is consistent with CBC.

Case 5 is the paradigm case of acting in willful ignorance, and A's culpability here conforms to the Added Culpability Thesis. In Case 6, I take it that A's culpability is the same as an analogous instance of Case 5, but because $\mathrm{p}$ is not true in Case 6, A generally will not face criminal liability. Suppose Brad intends to light a building on fire while suspecting someone is inside. If Brad decides not to investigate, then although he breaches DRI, he would not be convicted of the higher grade of arson that requires knowing a person is in the building (only a lower grade of arson). After all, the inculpatory proposition for the higher grade, someone is in the building, actually is false. Thus, Brad benefits from a sort of moral luck that is prevalent in existing criminal law. ${ }^{101}$ Finally, in Cases 7 and 8, CBC entails that A displays at least a little bit of insufficient regard in virtue of breaching DRI, even though A in fact ends up avoiding the wrong

\footnotetext{
${ }^{101} \mathrm{Cf}$. Alexander and Ferzan, supra note 16 at 171 (noting that under current law, "resulting harm makes an actor" subject to greater punishment, but arguing that this is problematic).
} 
in doing the actus reus. One might quibble with this result on the ground that if A does not do the actus reus, then since there is "no harm," there can be "no foul" (i.e. no culpability). Nonetheless, I think it's plausible in this case that breaching DRI can itself be a manifestation of insufficient regard, even if one ultimately declines to do the actus reus. However, this is of little practical concern, since whatever small amount of culpability A incurs by breaching DRI likely will be far below the amount that is plausibly required to make criminal liability warranted.

I do not have space to fully defend all the claims in this table. But doing so isn't necessary to vindicate the basic claim I need for my argument to go through—namely, that breaching DRI is an independent source of culpability beyond what one displays in virtue of doing the actus reus purely recklessly (i.e. when investigating is not feasible). Still, showing how complying with vs. breaching DRI systematically impacts culpability lends plausibility to the idea that DRI is a genuine and theoretically well-behaved pro tanto duty.

\subsection{How much culpability does breaching DRI entail?}

Suppose I'm right that breaching DRI entails that there is at least one respect in which one is more culpable than if one had not breached it (either because one complied with it or because it did not apply at all). One might then wonder how much additional culpability breaching DRI confers. I cannot fully answer this question, but let me mention several central factors. First, the amount of culpability it entails would be affected by the difficulty of acquiring more information about one's suspicions compared to not doing so. Specifically, the added culpability acquired from breaching DRI seems greater a) the easier it is to seek out relevant information, and b) the harder it would be to avoid additional information that one otherwise naturally would have received. Regarding a), if it requires little effort to find out whether one, say, is transporting drugs, then failing to investigate appears more culpable than if there are significant burdens in investigating (e.g. if it may get one shot). Regarding b), taking active steps to block oneself from 
learning facts that one otherwise naturally would have learned (e.g. if one takes a detour on the way to work to avoid seeing something one suspects one might) can be an especially egregious investigative failure. It would show that one not only is unwilling to bear the costs of seeking out more information, but that one also is willing to bear costs to avoid information that otherwise was coming one's way in the normal course of events. ${ }^{102}$

Second, DRI can be breached with different mens rea. Being willfully ignorant requires deliberately failing to investigate (i.e. consciously choosing to preserve one's ignorance). But one could also inadvertently breach DRI if one, say, forgets to investigate or is distracted from doing so. In that case, one would not be as culpable for the breach as if one consciously decided to preserve one's ignorance. Similarly, if one breaches DRI because one fails to realize that some method of investigation exists or that one should investigate (both forms of negligence), one would seem less culpable than if one failed to investigate while knowing that it's possible to investigate and that one should — as required for true willfulness. Thus, the breaches of DRI in willful ignorance will be more culpable, all else equal, than merely negligent breaches thereof.

Third, when one breaches DRI by consciously deciding to remain in ignorance (as required for truly willful ignorance), the decision can be supported by the justifying circumstances one is aware of. If one is aware of no circumstances that help justify the decision not to investigate (e.g. if one has no reason to believe that investigating would be dangerous or costly to others), then all else equal the decision not to investigate as DRI requires will be more culpable. After all, it would manifest more disregard for the protected interests of others. By contrast, if one is aware of serious downsides to investigating - e.g. if it risks injury to oneself or others, or conflicts with one's professional or familial obligations - then this can help justify the decision to remain in

\footnotetext{
${ }^{102}$ This might help explain why some courts require that the defendant take affirmative steps to avoid knowledge in order for a willful ignorance jury instruction to be appropriate. See, e.g., United States v. Giovannetti, 919 F.2d 1223,1228 (7th Cir. 1990). It would be another way to home in on especially egregious cases of willful ignorance.
} 
ignorance. It would, all else equal, make one less culpable for the decision to remain in ignorance rather than investigate as DRI requires. It would make this decision manifest less disregard for the protected interests of others.

Finally, while one's culpability for breaching DRI plausibly is greater the more serious the harm or illegality is that will be risked by the subsequent action one intends, note that this factor is not crucial for present purposes. After all, the truth of the equal culpability thesis depends only on whether the willfully ignorant defendant is as culpable as a similarly situated knowing wrongdoer-i.e. where the harm or illegality in question is the same in both cases. ${ }^{103}$ Thus, the seriousness of the risk that DRI requires one to investigate is not crucial for the present project of determining the proper scope of the equal culpability thesis.

\subsection{Willfully ignorant conduct can be as culpable as the analogous knowing misconduct}

How does all this support RECT4? If the Added Culpability Thesis is correct, it's easy to see how acting in willful ignorance can be at least as culpable as doing the same conduct knowingly. My account was supposed to explain how the decision to remain in ignorance can raise one's culpability up from the level of a purely reckless actor (where investigating is not feasible), $\mathrm{C}_{\mathrm{R}}$, to the level of the analogous knowing actor, $\mathrm{C}_{\mathrm{K}}$. Since willful ignorance always involves a breach of DRI, and since breaching DRI - according to the Added Culpability Thesis — makes one more culpable than if investigating were not feasible, acting in willful ignorance will at least sometimes be as culpable as the analogous knowing misconduct. In particular, when the extra culpability that the willfully ignorant actor incurs form his conscious decision to breach DRI is greater than or equal to $\mathrm{C}_{\mathrm{K}}-\mathrm{C}_{\mathrm{R}}$, then doing the actus reus of the crime in willful ignorance will

\footnotetext{
${ }^{103}$ See Alex Sarch, Beyond Willful Ignorance, 88 U. CoLO. L. REv. 97, 121-22 \& n.79 (2016) (discussing different ways the equal culpability thesis could be understood).
} 
be at least culpable as doing this conduct with knowledge. If the equal culpability thesis is restricted to this subset of cases - as is RECT4—we can be sure that it holds. ${ }^{104}$

Of course, RECT4 is non-vacuously true only if there are some cases of the sort just identified. But given the wide range of actors in the real world, we can be confident that there are some. The easiest way to see this is to note that some defendants will have a degree of belief in $p$ that is just short of knowledge. In such cases, $C_{R}$ will be quite high, so it won't take much extra culpability to get the actor up from $C_{R}$ to $C_{K}$. Since some breaches of DRI are more culpable than others, we can be quite sure that sometimes a deliberate breach of DRI will entail enough extra culpability to fill this gap.

\section{Objections}

Let me close by addressing some objections. First, one might object that DRI does not fit with standard accounts of conditional obligation. ${ }^{105}$ This account holds, roughly, that $\mathrm{A}$ has an obligation to $\phi$ conditional on $\mathrm{C}$ iff all of the best possible worlds, according to the relevant standard of evaluation, where $\mathrm{C}$ is true are also ones in which A does $\phi .{ }^{106}$ However, this seems not to hold for DRI. Some worlds in which the antecedent conditions of DRI are met and A fails to investigate still might be better with respect to culpability than some worlds in which the

\footnotetext{
${ }^{104}$ This highlights how my account of willful ignorance is importantly different from Tadros's, although it also relies on a duty to investigate. Cf. Tadros, supra note 16 at 246-47, 258-61. My account, premised on the narrow investigative duty DRI, is designed to answer a specific puzzle about how it can be that some reckless actors (who are aware of a risk that the inculpatory proposition is true) can nonetheless be treated as if they possessed knowledge. Thus, my account singles out a particularly egregious kind of (subjective) recklessness that can substitute for knowledge - as is needed to vindicate the willful ignorance doctrine. By contrast, Tadros is interested in whether willful blindness ever "manifests the degree and kind of vice for which the attribution of criminal responsibility is appropriate," and he argues that it can. $I d$. at 258. I don't take issue with this claim. But Tadros is not concerned, as I am, to home in on the worst cases of willful ignorance, which surpass mere recklessness and are as culpable as the analogous knowing misconduct. His account seeks to distinguish cases that are not appropriate for punishment at all from those that are. My account, on the other hand, focuses on cases that are already within the proper scope of criminal liability and defends a claim about precisely how culpable they are.

${ }^{105}$ Thanks to Jake Ross for this objection.

${ }^{106}$ See, e.g., Frank Jackson, On the Semantics and Logic of Obligation, 94 MIND 177 (1985) (discussing the "standard approach" to the semantics of ought claims, and conditional ought claims in particular).
} 
antecedent of DRI is met but A does investigate. For example, suppose A breaches DRI by not investigating, but then decides not to perform the actus reus of the crime. This scenario seems better than the one where A complies with DRI, learns that the inculpatory proposition is true, but then goes ahead and does the actus reus with full knowledge.

This objection admits of two answers (beyond rejecting the standard account of conditional obligation, as some have suggested ${ }^{107}$ ). First, one might back off the claim that there is a conditional duty to investigate, and instead say only that one has a weighty reason to investigate in virtue of intending the actus reus ${ }^{108}$ (though one might wonder exactly how reasons bear on culpability). The second response, which I prefer, is to recall that breaching the pro tanto obligation specified in DRI entails only that there is one respect in which one is more culpable than if one had complied with DRI. This allows that a person who fails to investigate still might be on-balance less culpable than someone who does investigate. This line of response also amounts to claiming that the standard analysis of conditional obligation does not apply to DRI. Specifically, the standard analysis of conditional obligation would at best apply only to claims about on-balance culpability, not pro tanto contributors to culpability (i.e. claims that acting in this way or that just reveals one respect in which one is more culpable). This is why CBC was formulated as it is in terms of contributors to culpability, not on-balance culpability. But it is also worth bearing in mind that all I need to secure RECT4 is the Added Culpability Thesis. Thus, even if the details of $\mathrm{CBC}$ require refinement, I can still succeed in my main aim.

A second objection concerns the overall structure of my account. Specifically, one might wonder why it is legitimate to add the culpability incurred from breaching DRI to that incurred from recklessly performing the actus reus. If these two quantities of culpability can be added

\footnotetext{
${ }^{107}$ Others have raised related worries for the standard view of conditional ought claims. See Jackson, $i d$. at 179-80.

108 Thanks to Gideon Yaffe for this response.
} 
together, why can't the reckless actor's culpability be supplemented by the culpability of other bits of misconduct she might perform (say, cheating on her taxes)? ${ }^{109}$

The answer is apparent when we recall that the notion of culpability that matters to the criminal law is one's culpability for a given course of action — not how defective one's character is in general. ${ }^{110}$ I've claimed that cases of willful ignorance decompose into two main components: i) breaching DRI and ii) performing the actus reus with suspicions of the inculpatory proposition (i.e. recklessly). These two components are tightly connected in that i) is an integral part of the deliberative process that gives rise to ii), and this is the reason the culpability inherent in i) is legitimately taken to augment that which ii) independently possesses. After all, i) and ii) form two parts of the same course of action. Part of the motivational process that issues in the willfully ignorant defendant's doing the actus reus is the information and apparent reasons he possessed while deliberating about how to act. What information he deliberates from, in turn, is a function of his failure to further investigate the attendant risks of the actus reus (i.e. whether the inculpatory proposition is true). Thus, the failure to investigate is a central part of the genesis of the willfully ignorant actor's performance of the actus reus and is legitimately considered together with it. Of course, there will be line drawing problems about where to say the process that generates some bit of behavior begins. But in general, the motivational and deliberative process that issues in a course of conduct is a proper basis for deciding how culpable that conduct is - as is clear from the fact that we decide, say, whether a homicide constitutes first-degree murder by asking whether it was premeditated. Accordingly,

\footnotetext{
${ }^{109}$ Thanks to Jake Ross, Steven Schaus and Gideon Yaffe for pressing me on this point.

${ }^{110}$ See supra notes 70-72 and accompanying text.
} 
one's culpability for failing to investigate can fairly be added to one's culpability for doing the actus reus recklessly. (In other work, I offer a more general reply to this sort of worry. $\left.{ }^{111}\right)^{112}$

\section{Conclusion}

My aim in this paper has been to home in on the conditions in which the equal culpability thesis holds. The importance of this task lies in the courts" "traditional rationale" for giving willful ignorance jury instructions. To remain faithful to this rationale, such instructions should be given only when the trial evidence plausibly shows that the defendant acted with a form of willful ignorance that rendered his conduct at least as culpable as the analogous knowing misconduct. ${ }^{113}$ Without an account of the conditions under which willfully ignorant misconduct is as culpable as knowing misconduct, then unfairness threatens-either by giving willful ignorance instructions when they are unwarranted or by arbitrarily stopping short of giving them in the full range of cases in which they are warranted.

I have argued that several common versions of the equal culpability thesis are false. Section 1 argued that the unrestricted equal culpability thesis is not true: sometimes willfully ignorant

\footnotetext{
${ }^{111}$ Alex Sarch, The Moral and Legal Contours of Culpable Ignorance, ch. 6 (manuscript on file with author) (defending a general theory of mens rea substitution that builds in a relatedness constraint of this sort).

${ }^{112}$ Holly Smith has also raised an interesting objection to duties to inform oneself, at least insofar as they are "subjective duties"-i.e. ones that arise in virtue of what one believes. See Holly Smith, The Subjective Moral Duty to Inform Oneself before Acting, 125 ETHICS 11, 23-31 (2014). She argues that it can't be the case that the sole reason we subjectively ought to investigate is that it would enable us to subsequently do the action that has the most "deontic value." After all, even though keeping a weightier promise has more deontic value than keeping a less weighty promise, it doesn't follow that one has an obligation to go around making more weighty promises. Likewise, one doesn't have a duty to go around investigating things just so that one will be able to do actions with more deontic value. I think Smith is right that there has to be more to it than that.

However, my view avoids Smith's objection. The trouble with the investigative duty she considers is that it takes the duty to investigate to be purely derivative of the deontic values of the subsequent acts that investigating, or not, would enable one to perform. However, as we saw, my view makes the duty to investigate non-derivative in Smith's sense. That is, I argued that there is an independently existing reason to inform oneself: namely, that not doing so can manifest insufficient regard for the protected interests or rights of others. Thus, on my view, there is something in itself good (or at least culpability-avoiding) about informing oneself in reasonable ways. It shows a kind of seriousness, conscientiousness and respect towards others.

${ }^{113}$ Such jury instructions generally may be given only if it can reasonably be inferred from the trial evidence that the defendant was willfully ignorant. See, e.g., United States v. Anthony, 545 F.3d 60, 64 (1st Cir. 2008); United States v. Reyes, 302 F.3d 48, 55 (2d Cir. 2002); United States v. Abbas, 74 F.3d 506, 513 (4th Cir. 1996).
} 
misconduct is not as culpable as the analogous knowing misconduct. In Section 2, I argued that it is also problematic to restrict the equal culpability thesis to just those cases where the defendant remained ignorant to preserve a defense against liability. After that, I considered more plausible approaches to restricting the thesis. However, as argued in Section 3, the counterfactual approach offered by Michaels and Luban risks punishing merely for character, not for one's actual conduct. Moreover, section 4 argued that Hellman's approach, while promising, also faced difficulties. Finally, in Sections 5 and 6, I defended my own version of the thesis. I suggested that willfully ignorant misconduct is at least as culpable as the analogous knowing misconduct just in case the defendant breached her duty of reasonable investigation in sufficiently serious ways before performing the actus reus.

If I am right, then willful ignorance jury instructions should only be given when it can reasonably be inferred from the trial evidence that the defendant satisfies the conditions picked out by my account. Thus, my account provides guidance for deciding whether willful ignorance jury instructions are warranted. In particular, the relevant decision-maker should consider two sorts of question. First, it should be asked how much confidence the defendant had in the inculpatory proposition when acting - and, in particular, how much below the knowledge threshold her degree of confidence in that proposition was. The closer she is to the knowledge threshold, the less of a culpability gap there is to be filled before she becomes as culpable as a similarly situated knowing actor. Second, it should be asked how much additional culpability the willfully ignorant defendant incurred by breaching her duty of reasonable investigation. This, in turn, depends on several factors. Did the defendant perceive serious costs, dangers or difficulties in investigating her suspicions about the inculpatory proposition? How justifiable or unjustifiable was the decision to remain in ignorance under the circumstances the defendant was aware of? Was she merely trying to set up a defense against liability, perhaps, or was she aware of 
justifying circumstances that plausibly support not investigating - e.g. dangers from doing so, or her professional or familial obligations?

On my account, the answers to such questions provide the raw material from which to form a judgment about whether a given willfully ignorant defendant is as culpable as a similarly situated knowing wrongdoer. Granted, the suggested inquiry is multifaceted and simplifications may be required in order to apply the account in practice. ${ }^{114}$ Thus, it may be prudent for courts to adopt only some approximation of the approach defended here. Nonetheless, the defense of the equal culpability thesis I have offered lays bare the sort of inquiry to be undertaken in deciding whether willful ignorance jury instructions are appropriate in particular cases.

${ }^{114}$ I discuss some such simplifications elsewhere. See Sarch, supra note 44 at 1094-1101. 